\title{
State of the Art Compendium of Macro and Micro Energies
}

\author{
Mushtaq Ahmad ${ }^{1 *}$, Salmia Beddu', Zarina binti Itam ${ }^{1}$, Firas Basim Ismail Alanimi \\ 1 Department of Civil Engineering, Universiti Tenaga, Nasional Putrajaya Campus, Malaysia \\ 2 Department of Power Generation, Research Centre, Universiti Tenaga, Malaysia \\ * Corresponding author's e-mail: ma_5099@yahoo.com
}

\begin{abstract}
In the span of past few decades, population, urbanization and industrialization have transformed the mankind living standard and dynamics of the nature. Certainly, energy is the basic need for all living organisms. Energy is the route towards the economic growth. The evidence shows that the countries faced with energy crises are left behind in the economic activities; as a result, people are deprived. This study reviewed the available renewable energy resources and potential with positive and negative aspects. This study comprehensively discusses the renewable macro and micro energy resources studied in the past two decades reported in various studies. The paper is divided into two sections; the first section discusses the energy produced in the macro level and the second section discusses the energy produced using different strategies and techniques in the micro level. The potential and positive outcomes of the energy resources were identified. New paradigm of micro energies and importance of reusing the available resource of micro energy using different resources like energy harvesting on the road surface, vibration, airflow, radio frequency and thermal energy etc. were discussed. Lastly, the study focus does not only review but also finds the potential and opportunities for the researchers in the future to utilize the renewable energy resources.
\end{abstract}

Keywords: macro and micro energy resources, renewable energy, renewable energies potential.

\section{INTRODUCTION}

In order to satisfy our requirement for power (electricity) "We are drilling holes miles deep under the surface of oceans, fracturing stones in the crust of the earth, transporting fuel in a huge ships and pipelines from one side of the earth to the other to operate machinery to produce electricity" [1]. The bitter truth about rapid changes of anthropogenic origin

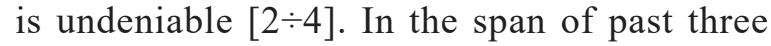
decades, population, urbanization and industrialization have transformed the living standards of mankind and dynamics of the nature. Certainly, energy is the basic need for all living organisms and a route towards the economic growth $[5,6]$. In the span of quinquennium, a large part of population has migrated to cities and 3.0 billion is forecast to follow in 2050 [7]. The growing energy demand gap was bridged with the energy produced from fossil fuels. As a result, fossil fuels were found to be the key contributor to the emission of greenhouse gases $(\mathrm{GHG})$, especially the carbon dioxide $\left(\mathrm{CO}_{2}\right)$ released to the environment. Over the past 15 years, unprecedented changes in the consumption of energy resources caused a drastic impact on the environment. The trend towards investment and utilization of green and renewable energy has increased worldwide [8]. The purpose of this research was to gather information on the macro and micro level energy produced and development by different countries. The up-to-date data and materials published by the world energy councils, renewable energy resources, renewable energy review reports and other research papers were reviewed. This paper will help the researchers to identify the area and potentials of renewable energies like new areas in the micro level energy generation and storage, which are hot topics among engineers and scientists. 

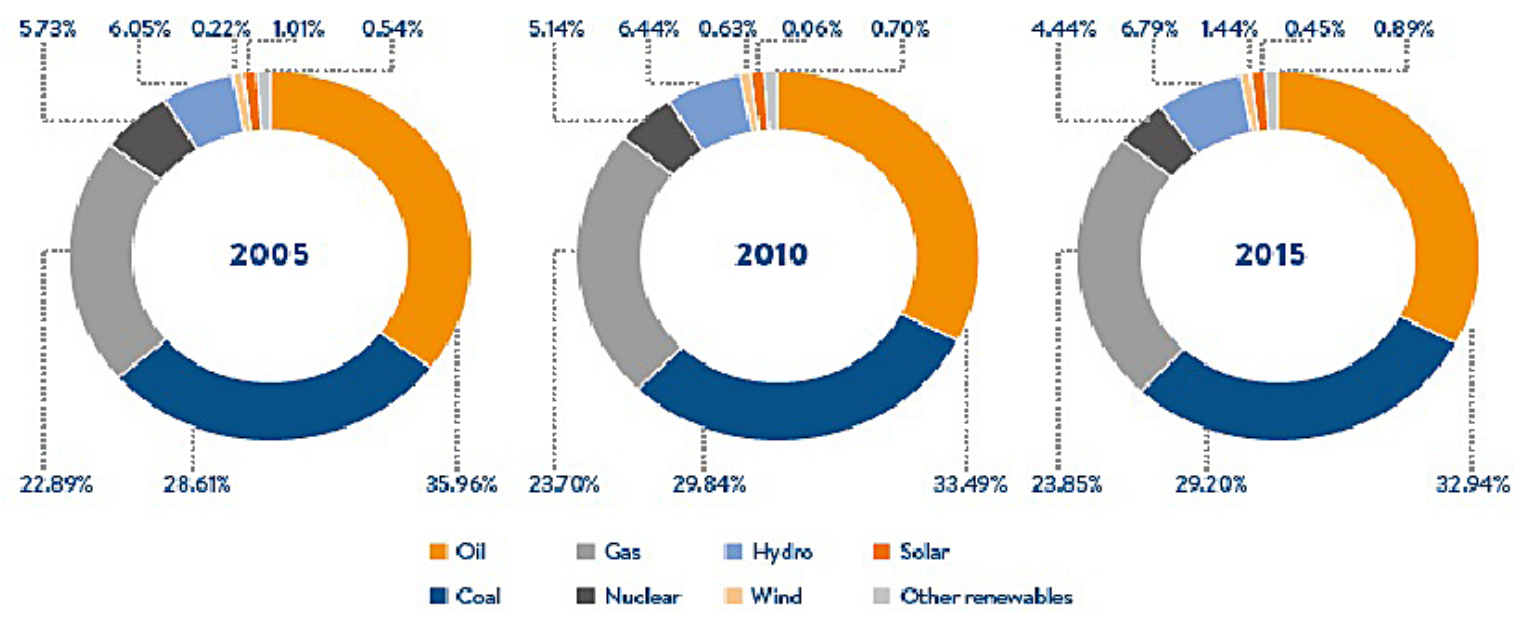

Fig. 1. Comparison of the energy resources and consumption [8]

\section{POTENTIALS RENEWABLE ENERGIES RESOURCES}

The comparison of available energy resources and its consumption for over past 15 years have been reported by world energy council [8] and British Petroleum BP [9], as shown in Figure 1. Oil remained the world's leading fuel consumption in 2015 , which accounted for $32.95 \%$ of the worldwide energy consumption.

The depletion and negative impact on the environment are the greatest obstacles to the utilization of non-renewable energy resources. Thus, to address the issue of insistent pressure on the utilization of non-renewable resources, a series of studies have been carried out to use the renewable and sustainable resource to produce energy. Scientists and engineers are always keen on renewable energy resources to eliminate the dependency of mankind on the non-renewable energy resources. Furthermore, reducing the greenhouse gases (GHG) effect on Earth and protecting the global environment for the future generation is the top priority. Extensive technologies have been established to produce safe, green and renewable energy but they are far too slow compared to the non-renewable energy consumption [9].

The World Energy resources [8] statistics shows that the input of total renewable energy to the global energy grew significantly in 2015. Figure 2 shows the global renewable energy accounted for $23.5 \%$ of the total energy consumption in 2015 [10]. However, the contribution of renewable energy is far slower than the non-renewable energy consumption by resources [10] where the potential to generate renewable energy is large [11].

The access to the sustainable energy is one of the greatest challenges facing the world. Nature can inspire innovative solutions for future energy systems and technology design; some renewable energy technologies have been found available in nature. However, more can be learnt to help

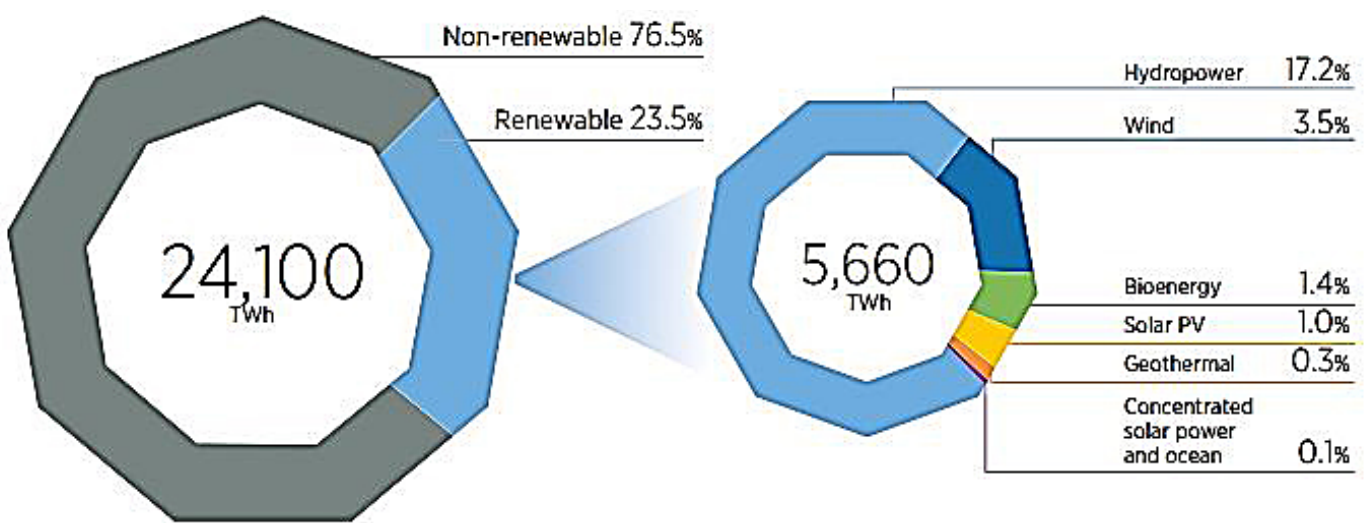

Fig. 2. Global energy produced by sources 2015 [10] 


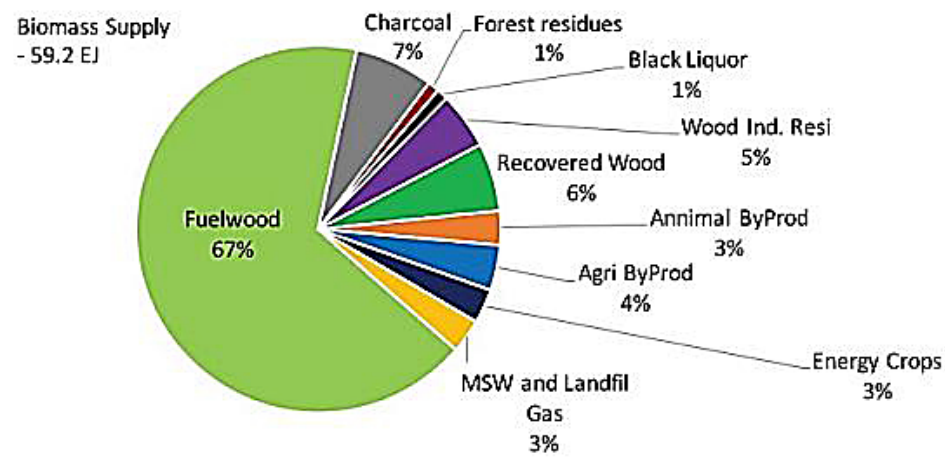

Fig. 3. Primary sources of Bioenergy [16]

us successfully address our future energy needs. Major developments in the renewable energy resources are overlooked in the current scenario. Figure 2 shows the macro and micro renewable energy resources and each is briefly discussed to understand the potential and gap.

\section{MACRO ENERGY}

\section{Hydropower Energy}

Most of the renewable energy sources originate from the natural movement of air and water/ fluid [12] and the hydro energy is derived from the energy of moving water.

Blowing air and flowing water create energy which can be stored and utilized. The hydropower energy is generated from the flowing water and by using mechanical technology such as turbines to convert the energy and further increase the supply. Hydropower generates energy on a macro scale and which is supplied over large distance but, unfortunately, not all countries have the hydropower potential [13]. According to the world Energy Resources [8], amongst the renewable energy resources, the hydro-energy is leading and globally supplied $71 \%$ at the end of 2015 . In addition, the globally underdeveloped potential is estimated at 10,000 TWh/y; between 2007 and 2015 the total capacity has increased by $30 \%$. Approximately 10,000 TWh/year of unutilized hydropower potential exists worldwide and offers many opportunities for hydropower development. According to IRENA, [10] the countries producing more than half of the global hydropower energy are China (1126 TWh), USA (250 TWh), Brazil (382 TWh), Canada (376 TWh), India (120 TWh) and Russia (160 TWh).

\section{Bioenergy}

Bioenergy is a versatile source of renewable energy and biomass can be converted into solid, liquid and gaseous states of energy. The use of bioenergy can significantly reduce the greenhouse gas emission [14]. In developed countries, bioenergy is promoted as an alternative or more sustainable source for hydrocarbons, especially for transportation fuels like bioethanol and biodiesel. There are multiple challenges and opportunities for bioenergy as a potential driver of sustainable development given enough economic and technological support. According to the World Bioenergy Association [15], bioenergy has the largest contribution of $14 \%$ from the total $18 \%$ renewable energy and global supplies amount to $10 \%$ of all renewable energies. The bioenergy sources exist in many forms and the biomass energy comes from different sources like wood, forestry residues, charcoal, pellets, agriculture crops and residues, municipal and industrial waste, biogas, biofuels etc. The key suppliers of the biomass energies are categorized into forestry, waste and agriculture. Biomass annual growth rate is $2.3 \%$, whereas biogas $-11.2 \%$ and liquid biofuels- $15.6 \%$, experience highest increase. Forestry is the main contributor with $87 \%$, followed by agriculture $-10 \%$, and municipal solid waste with landfills gas contribute $3 \%$ of the biomass key energy generators.

Electricity produced from the bioenergy is the third largest renewable source. Bioelectricity generated in 2014 was 493 TWh and solid biomass majorly contributed to this value [15]. The impact on climate using bioenergy is significant by reducing greenhouse gases. However, in the development process, transportation, conversion bioenergy might have some carbon inputs but the overall life cycle and supply chain has the greatest benefit to the climate [10]. 


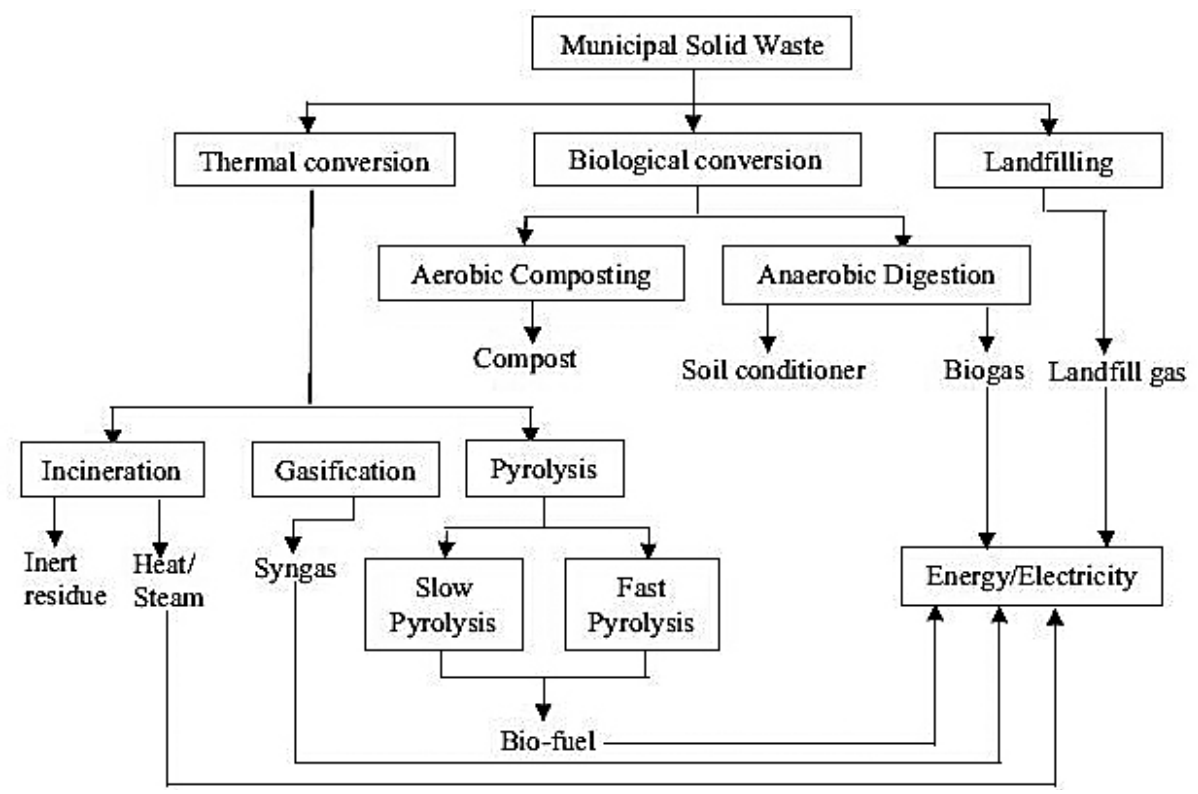

Fig. 4. Municipal solid waste treatment techniques and their products [19]

\section{Waste to Energy}

Waste to Energy (WTE) is the sustainable approach to generate energy (electricity) by utilizing municipal solid waste. Reuse of waste products to recover energy in the form of electricity or heat is the most appropriate method to solve the waste problem [17]. Waste to energy is the source of renewable energy which is economical, feasible and eco-friendly $[18,19]$. Comparatively, the waste to energy production is lower than fossil fuel but since the aim is to reduce the municipal solid waste, the best way to recycle is to generate electricity. Different technologies can be used to obtain energy from the waste products [20]. Figure 4 shows the clear picture of technologies use in the energy conversion process.

Globally, an average waste generate per person per day amounts to $1-2 \mathrm{~kg}$ [21] but the potential of WTE operation strongly depends on the country economic, social, political conditions [20]. In the high income countries, the implementation of waste to energy is easier by using various technologies than in the low income countries $[20,22]$. Thus, the adoption of waste to energy has been more advanced in the developed countries [19]. In some studies, the impact of implementation of WtE constitutes a risk to the climate, as WtE is the big contributor of the methane gas to the environment [23, 24]. In contrast, a study of [25] stated that reusing of waste product will bring the positive influence on the climate change. Waste plastic products, followed by papers, textile and other waste organic materials have high potential for the reuse of waste and energy production. Three types of technologies are mainly used to convert solid waste into the useful energy, i.e. biochemical extraction, thermochemical extraction and mechanical extraction [26].

\section{Solar Energy}

The infinite and free source of energy existing in our planet is the Sun. The sun radiates massive heat energy every day $[1,27]$. The Sun energy radiation is greater than the energy consumed annually by the world population $[8,27]$. Sunlight has the highest potential of producing renewable energy [28]. The sun is composed of hydrogen and helium atoms and generates its own energy from the process of nuclear fusion [27]. The estimated average solar energy hit at earth surface is 342 $\mathrm{W} / \mathrm{m}^{2}$. The Earth surface received a small portion of solar heat energy, where $30 \%$ was reflected back into the space from the $70 \%$ and major part absorbed by the land and oceans. The effective yearly available solar irradiance in different parts of the world is $60-250 \mathrm{~W} / \mathrm{m}^{2}$, the geographical location is an essential part of solar irradiance $[1,8$, $27 \div 31]$. The solar energy has wide application in the daily life [28]. Solar energy powers the water cycles which move the water and energy can be harvested from the moving water [12]. 


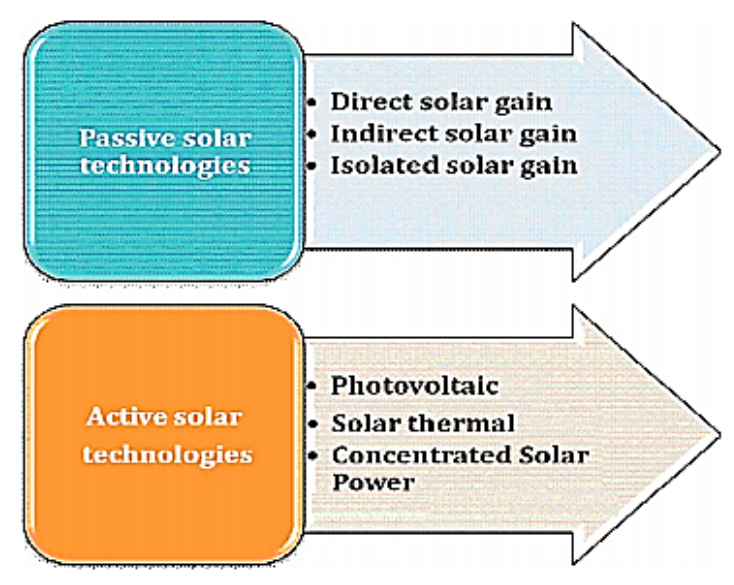

Fig. 5. Solar energy classification [28]

Solar energy drives the wind which allows running the turbines and producing electrical energy from the kinetic energy. Plants use the solar energy in the process of photosynthesis. Biomass can trace its energy source back to the sun. Even fossil fuels originally received their energy from the sun and solar energy can also be harvest in the macro level by embedding different energy storage and conversation instruments. Solar energy has been used for centuries as in the ancient time people used magnifying glass to focus sunlight and make a fire [1]. With the advancement of technologies, solar energy has been used for water heating and solar energy gas been collected to make steam and run an engine [28]. Harvesting and utilization of solar energy is the key concept by using active and passive technologies to obtain the advantages of producing solar electricity [32]. Solar energy collection, storage and distribution in the form of heat without transforming into the electrical energy are categorized as passive solar energy. In contrast, solar energy collection and using mechanical or electrical technologies to convert heat energy into power energy or other meaningful energy is categorized as active solar energy, as shown in Figure 5.

Massively available source of solar energy, with the highest potential to produce energy at minimum cost and high efficiency compared to other renewable sources of energy, is highly recommended in many countries $[33,34]$. Extensive research has been published on the potential, economic and environmental aspects value of the solar energy where scientists successfully launched several active and passive technologies to collect, store and convert solar energies from one form to another. Recently, governments in many coun- tries have taken initiative to produce solar/clean energy on a large scale but the developing countries are still far from the usage of technologies. Figure 2 shows the global contribution of solar energy to the renewable amounts to $1.0 \%$ [10].

Different regions on Earth receive more or less solar irradiance. Some regions on Earth may be more suitable for collection and generation of solar energy [35]. Rapid growth and high demand for solar energy occur across the world. There are few barriers in the acceptance and implementation of solar energy on large scale such the high cost [33]. The potential and performance efficiency of the solar energy is highly dependent on the geographical location, sunshine intensity, wind speed, cloudiness $[35,36]$. The awareness and acceptance among rural populated area was found as a barrier which should be overcome and people should be educated with the potential benefits of solar energy [33]. Globally, solar powered electricity generation reached $227 \mathrm{GWe}$ at the end of 2015 and total estimated capacity of solar energy is 406 GWe. Photovoltaic energy is the mainstream solar power energy which drastically increased in the last few years. China is leading in terms of solar PV panel installation 23\% followed by the USA - $14 \%$, Japan - $14 \%$, Germany $-13 \%$, and - Italy $6 \% ; 30 \%$ PV installation corresponds to the rest of countries on Earth $[8,9,30]$.

\section{Geothermal Energy}

Earth's interior contains a massive amount of heat energy also known Geothermal Energy [3739]. Over the past few decades, the global capacity of geothermal energy has increased at the rate of 3-4\% annually [37]. Geothermal energy is a clean renewable energy source with the highest capacity factor up to $90 \%[37 \div 41]$.

Although geothermal energy emits some level of greenhouse gases to the environment, the continuously restoring heat energy in the Earth's crust make it renewable energy. Among the primary energy resources referred to in Figure 2, the geothermal energy contribution is the least to

Table 1. Capacity factor comparison [41]

\begin{tabular}{|c|c|}
\hline Technology & Capacity Factor (\%) \\
\hline Geothermal & $89-97$ \\
\hline Biomass & 80 \\
\hline Wind & $26-40$ \\
\hline Solar & $22.5-32.5$ \\
\hline
\end{tabular}




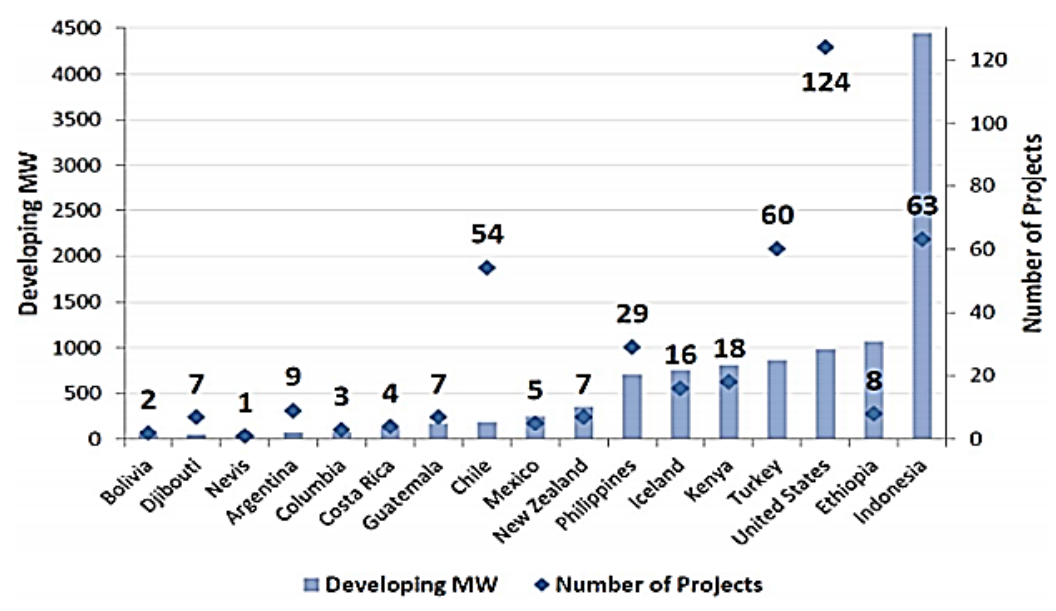

Fig. 6. Countries with over 50MW geothermal energy capacity [41]

the world energy consumption and production, as less than $1.0 \%$ electricity is produced from geo-

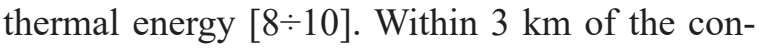
tinental crust, the roughly estimated geothermal energy is 43 x106 EJ [8] and the available geothermal energy reserve can supply energy for approximately 217 million years [37].

Since 1950s, geothermal energy has attracted many countries [41]. About 315MW new geothermal plants were installed and raised the global total capacity from $11 \mathrm{GW}$ in 2010 to $13.5 \mathrm{GW}$ in 2015 [8, 10, 37, 41]. Indonesia and Turkey are the leading countries in geothermal energy followed by United States, Mexico, Kenya, Japan and Germany $[8,41]$. Among other countries, Malaysia is also very concerned and actively seeking renewable energy resources. Tawau geothermal plant is the first geothermal plant in Malaysia expected to start operation in June 2018 with maximum capac- ity of electricity generation 30MW [42]. Generally, two methods are used to produce electricity from the geothermal field. The steam extracted from the geothermal field runs a turbine directly or using hot pressurized fluid to create steam from the low boiling point liquid to operate the turbine [41].

The Earth's natural heat reserves are immense and geothermal energy has the highest capacity factor over other renewable energy technologies. Geothermal energy can play an important role in the countries that have the potential. In the developing economies like Pakistan, Kenya and Indonesia, the geothermal potential can play a key role to produce electricity and overcome the energy crises.

\section{Wind Energy}

Globally, wind energy is the fastest growing resource of renewable energy and well-proven in

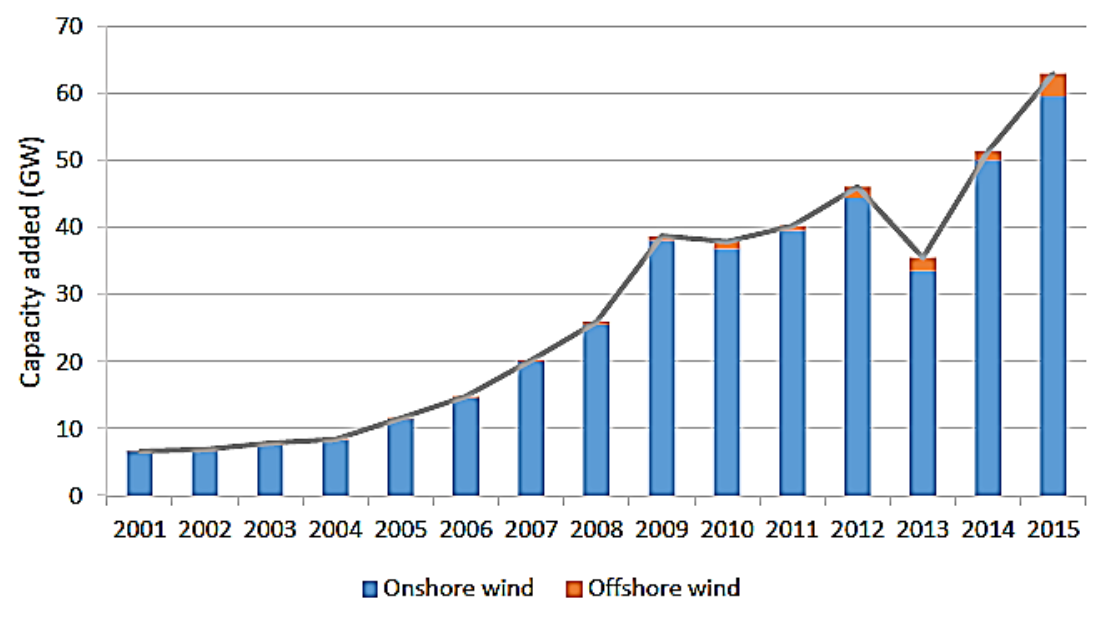

Fig. 7. Global addition of wind capacity [10] 
terms of cost-effectiveness [43]. In 2015, wind global growth rate was $17.2 \%$ and wind power generation capacity reached $435 \mathrm{GW}$ [8]. According to World Energy Resources [8] estimated the wind power generation is $950 \mathrm{TWh}$ which is $4 \%$ of the global renewable energy shown in Figure 3. Denmark produces the highest $42 \%$ wind power, whereas in Germany the wind power contribution reached to $13 \%$ in 2015 . Wind power can be generated from onshore and offshore. Figure 7 shows the global addition of wind power.

Wind power output is highly dependent on the wind speed [44:45]. The output increases with wind speed and remains constant above the design wind speed. Wind turbines do not produce wind energy on low or very high wind speed, and stop working as a result. The wind power management is an important issue for the large scale wind power grid. The wind power capacity factor changes and depends on the wind speed. Site to site capacity factor for wind power is different. In the UK it reached 26-35\% onshore and the offshore wind capacity in Denmark reached to 41$50 \%[44,46]$. Wind power generation typically depends on three factors: the turbine type (vertical/horizontal axis), installation of wind power (onshore/offshore) and grid connectivity (connected or standby). Horizontal wind turbine is most commonly used with possibly two or three

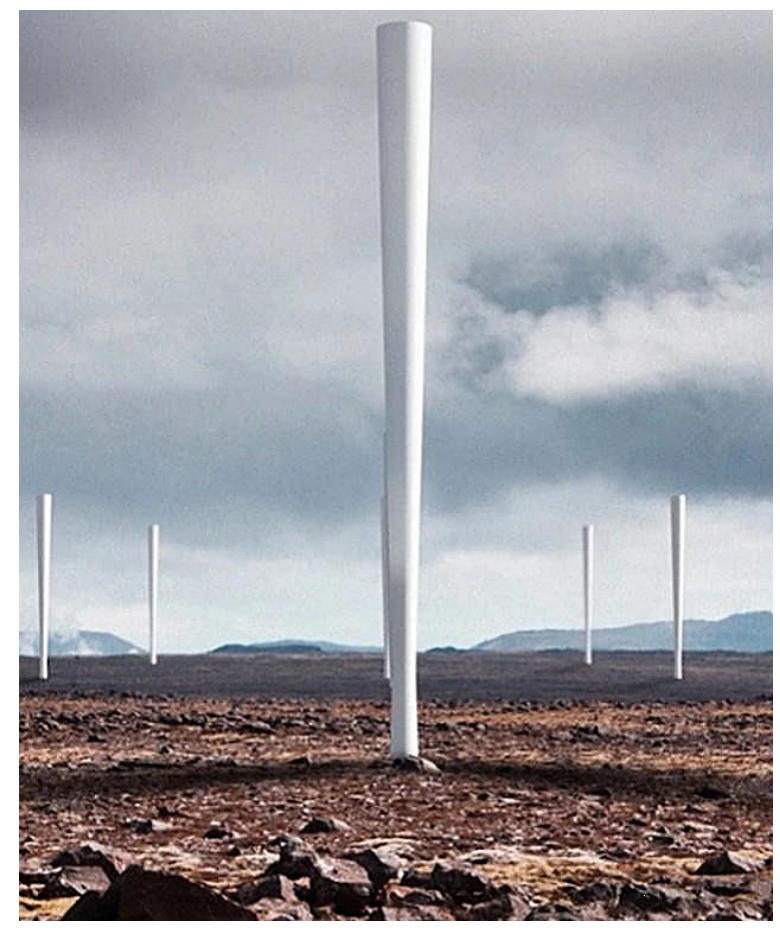

Fig. 8. Vortex Bladeless, Altaeros Energies [8] blades $[44 \div 45]$. In order to overcome the environmental and other wind speed limitation issues, an alternative design called Vortex without rotor blades has been introduced by Spanish to harvest wind energy, as shown in Figure 8. The turbine is run through the vortices phenomena [8].

Airborne is the latest wind generation technology among Google's Makani Project which is a kite type device tied to the ground and rotated in orbit producing electricity. Buoyant airborne turbine (BAT) by Altaeros Energies consists of a conventional HAWT suspended and held afloat in a helium filled shell. Airborne wind solutions are emerging designs yet to reach commercial viability due to the challenges related to cable loading, the impact of lighting and storms and the interferences with aircrafts and radars [8]. Wind power generation is an old technology but a recent trend in terms of searching for new sources of renewable and clean energy to reduce dependency on fuel energy, which has enabled to review wind energy in the recent era [45]. In the past few decades, major and advanced development occurred in the wind power, especially in the developed countries.

\section{Marine Energy}

Marine is more viable and represents an immense source of renewable energy [8, 47]. Marine energy can play a significant role in the energy production to solve the current energy crisis as well reduce the climate change effect $[47 \div 50]$. To date, the globally installed marine energy is over $530 \mathrm{MW}$ and if the undergoing proposed projects of marine energy are implemented, estimated 750 GW by 2050 will be produced globally $[8 \div 10]$. This part examines the overview of sub-categories of marine energy technology which is divided into seven groups: ocean wave, tidal range, tidal current, ocean current, ocean thermal energy, salinity gradient and ocean thermal energy conversion $[47,51 \div 53]$. The collective estimated oceans energy is $20,000 \mathrm{TWh}$ to $80,000 \mathrm{TWh} / \mathrm{yr}$ which is $400 \%$ more than the present global energy demand [10]. Most of the technologies to produce electricity from marine energy are at the early stage of development except tidal range [51]. Under this section, some short compressive review of the off shore technologies is reviewed.

\section{Waves Energy}

Oceanic waves are the most advance and developed category. Wave energy contributes 


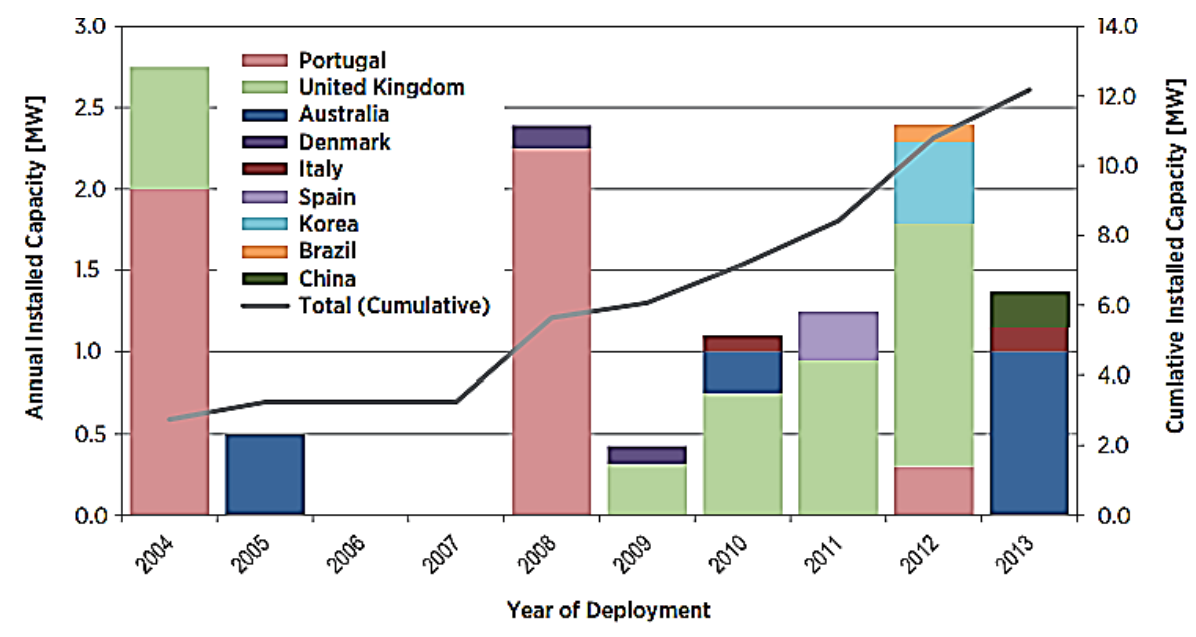

Fig. 9. Large scale wave energy deployment [10]

significantly to the power generation $[51 \div 54]$. Strong wind blows over the ocean surface due to the temperature and pressure variation; waves are produced as a result. The waves carry kinetic and gravitational energies. According to Antonio, [55] more than 50 types of different technologies are under development to harvest the energy from the waves such as oscillating buoys, floating ducks, snakes, flaps and enclosed chambers. Scientists are striving for the better improvement and enhancement of the efficiency characterizing the developed wave's technology. A study conducted by Mork, [56] presented that the total theoretical wave energy potential is $32 \mathrm{Pwh} / \mathrm{yr}$ which is double the total global energy 17Pwh/yr supplied in 2008 [8]. Regional distribution of the global yearly wave energy potential is shown in the Table 2 . Some of the-

Table 2. Wave Energy regional potential [56]

\begin{tabular}{|c|c|}
\hline Region & $\begin{array}{c}\text { Wave energy potential } \\
\text { (TWh/Year) }\end{array}$ \\
\hline Western and Northern Europe & 2800 \\
\hline $\begin{array}{c}\text { Mediterranean Sea and Atlantic } \\
\text { Archipelagos (Azores, Cape } \\
\text { Verde, Canaries) }\end{array}$ & 1300 \\
\hline $\begin{array}{c}\text { North America and Greenland } \\
\text { Central America and South } \\
\text { America, }\end{array}$ & 1500 and 4600 \\
\hline Africa & 3500 \\
\hline Asia & 6200 \\
\hline $\begin{array}{c}\text { Australia, New Zealand and } \\
\text { Pacific Islands }\end{array}$ & 5600 \\
\hline $\begin{array}{c}\text { Total estimated regional wave } \\
\text { energy potential }\end{array}$ & 29,500 \\
\hline
\end{tabular}

oretical predicated waves energy has been tested practically and validated at laboratory scale [57].

\section{Tidal Range, Current and Stream}

Tides current is defined as vertical rise and fall of ocean water. In the marine science, tidal stream is caused due to the gravity forces between the Earth, the Sun, the Moon and other plants [ $58 \div 59]$. Globally, most often oceanic tidal stream occurred twice a day $[10,59]$. Tidal range is the difference in sea level height between high and low tide at a given location. Tidal range depends on the geographical location and position of the Sun and Moon. In contrast, temperature and pressure variation on the oceans create strong winds; as a result, the oceanic's water circulation produces tidal current. The velocity of tidal and oceans current is often more than $1 \mathrm{~m} / \mathrm{s}$ which may produce energy [57]. Generally, two methods to produce energy from the tidal or convert tidal energy into electrical energy were adopted. Tidal range has potential to produce energy between high and low tides. The second commonly adopted method is hydrokinetic energy production from the horizontal flow of tidal current [10]. Tidal current energy potential depends on the tidal range; the greater tidal range the higher energy can be captured from the tidal current [58]. Global total tidal (stream and range) potential is estimated at about $3 \mathrm{TW}$ where $1 \mathrm{TW}$ is located relatively shallow water $[59 \div 60]$. There are several factors and hurdles in harnessing tidal energy like geographical location of the site and environmental constraints. Most of the coastline across the sea has potential to produce tidal energy [59]. 


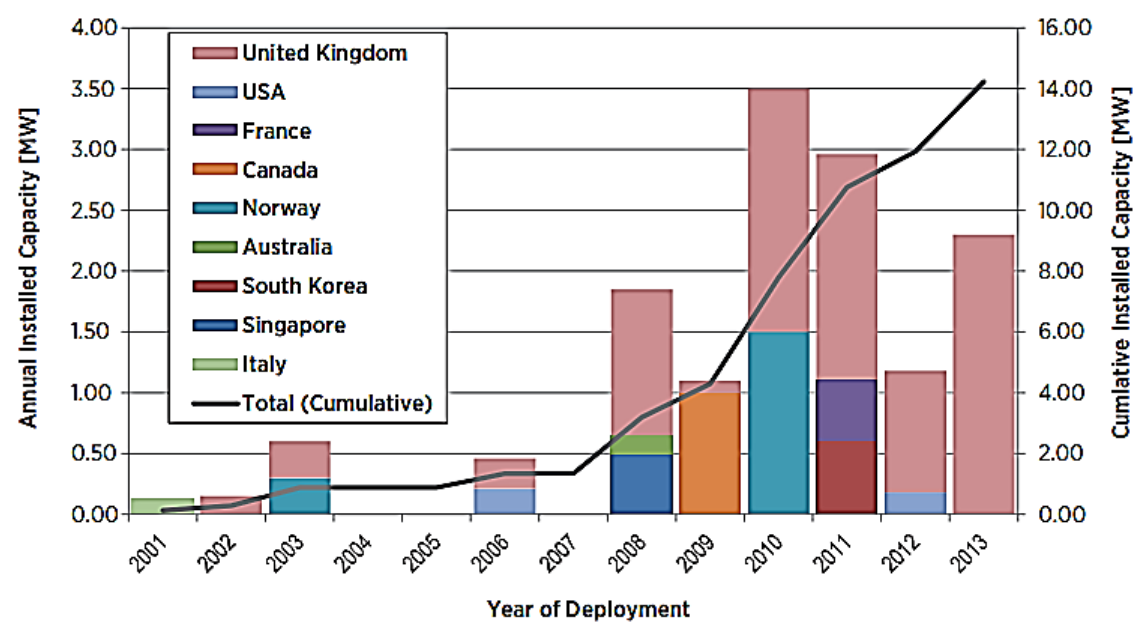

Fig. 10. Large scale Tidal stream deployment [10]

\section{Ocean Thermal Energy Conversation (OTEC)}

Oceans receive a substantial amount of solar energy, approximately $15 \%$ of the total incident on Earth $[8,10,47,52,57,61]$. The incident solar energy is stored in the upper layers of the oceans. Temperature gradient difference can exceed more than $25^{\circ} \mathrm{C}$ between the ocean's surface water at 20 meter depth to the depth of $1000 \mathrm{~m}[52,60 \div 62]$. Ocean's thermal energy conversation (OTEC) is the process converting the temperature gradient present between ocean's surface water to deeper cold water using various conversation technologies. The OTEC technologies effectively work if the temperature gradient is $20^{\circ} \mathrm{C}$ [54]. However, seasonal effect - summer to winter - changes the temperature gradient but it is considered as continuously available. The estimated total OTEC potential is 30-90 $\mathrm{PWh}[47,63]$. OTEC has proven high cost although open cycle and closed cycle as well as hybrid OTEC technologies have been developed and tested in the USA, India and Japan $[8,57]$. Open cycle and closed cycle technology of OTEC generates desalinated water which can be used for drinking and irrigation, while cold water can be used air conditioning. The benefit of OTEC is that the cold water extracted from the deep sea is rich with some natural minerals can be used for agriculture and in the medicine[64]. OTEC has a high capacity factor of $90-95 \%$ but very low efficiency of 7\% [65].

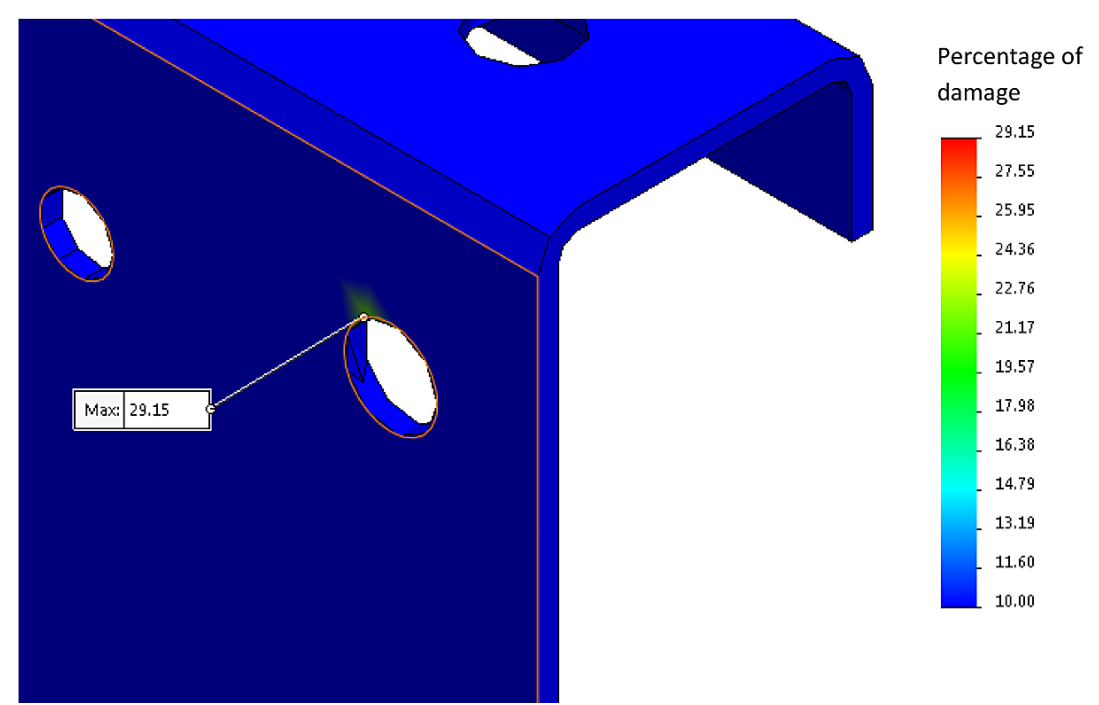

Fig. 11. Pressure retarded Osmosis [72] 


\section{Salinity Gradient}

Salinity gradient energy (SGE), also known as blue energy [66], was discovered in 1950s $[67 \div 68]$. Natural mixing of fresh and salt water produces large amounts of energy gradient [69]. The global potential of SGE is determiend based on Gibbs free energy equation and presumed to equal 1.4-2.6 TW.h [70]. Pressure retarded osmosis (PRO) and reversed electro-dialysis (RED) are the methods used in SGE. Pressure retarded osmosis (PRO) technology of salinity gradient energy was introduced by Norwegian energy company [71]. Under the chemical process water of dilute solution flows toward higher concentrated solution, the movement of two different solutions produces gradient; as a result, turbines rotate and transform the mechanical energy into the electrical energy [66 $\div 69]$. First pressure retarded osmosis (PRO) plant energy producing capacity of $5 \mathrm{kw}$ was opened in 2009 at Tofte, Norway but closed operation due to a technical fault [57, 72]. Reversed electro dialysis (RED) plant was open in 2014 at Afsluitdijk the Netherland but due to membranes damaging, impurities in sea water and difficulties in filtration, the plant was closed. The developed technologies are underpinning to some serious issues addressed by engineers and future studies are recommended to overcome the challenges mentioned by the recent studies of [66 68 ].

\section{MICRO ENERGY}

The contribution of renewable energy is far slower than the non-renewable energy consumption $[73 \div 74]$ where the potential to generate renewable energy is large $[8,10,73,75]$. In the era of technological war of rapid growth, especially mobile electronics consuming micro level energies increase in the quantities and may consume large amount of energy. Micro level renewable energy constitutes an alternative to the macro energy resources, which needs heavy investment and long planning $[75 \div 76]$. Self-powered technique is used to harvest the energy from the surrounding environment such as thermal variations within the body create light, thermal gradient, pressure gradient, air flow, vibration, motion radiofrequency or electromagnetic radiation are the example of micro scale energy harvesting. Selfpowered energy harvesting is a growing interest to the research community facing many chal- lenges and limitations in the design. The energy generated from the solar radiant is found the best among all others and is clean, eco-friendly and infinite source of energy $[1,8,73,76 \div 83]$.

\section{Vibration}

Likewise other sources of energy waste vibration create energy which can be usefully converted to electrical energy and can replace small batteries use for sensors or wireless communication devices [ $84 \div 85]$. Three main causes of vibration are seismic vibration, acoustic vibration and vibration caused by the application of load [84]. Seismic vibration is caused by the human walking, vehicle traffic and wind blowing, etc.. Human motion and others sources of vibrations have the potential to produce energy and can be harvested. The magnitude of the vibration energy depends on the frequency and amplitude of the vibration [84 $\div 89]$. The mechanism of energy harvesting from the vibration using electrostatic, piezoelectric and electromagnetic transduction was recognized [84, 90]. Beeby, [91] developed a electromagnetic energy harvester which consists of a coil and a silicon wafer cantilever beam, with four pole magnets as its proof mass. Roundy, [92] developed piezoelectric to harvest micro scale energy from the vibration sources. Using the vibration energy harvesting concept Minazara, [93] developed a piezoelectric generator and installed it in the handlebar of bicycle to convert the available mechanical energy and power the LED lamp of the bicycle. Human body, especially while walking, has a potential to produce energy [84, 88, 89, $90,94]$. The kinetic energy from human walking can be harvested and converted to electrical ener-

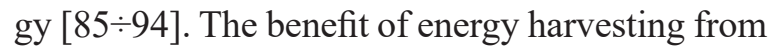
vibration is not only useful for batteries recharge or replacement but also reduces the cost of the batteries and maintenance. Moreover, it minimizes the power consumption also has a positive influence on the environment. Many studies conducted on vibration and motion energy and have attracted the researchers' attention in the area of micro scale vibration and motion energy. Wei, [84] listed and compared the maximum potential output among piezoelectric, electromagnetic and electrostatic vibration energy harvesting techniques with the maximum output energy $2.45 \mathrm{e}-5 \mu \mathrm{W}$ to $2.7 \mathrm{e} 4 \mu \mathrm{W}$. It was concluded that vibration and motion have potential to harvest and convert mechanical/kinetic energy into electrical energy on a micro scale. 


\section{Radio Frequency}

The environment is filled with radio frequencies (RF) generated from various wireless devices such as mobile tower, radio, television, satellite

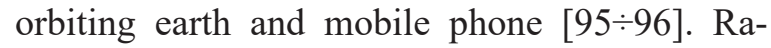
dio frequency $(\mathrm{RF})$ energy transmitting from the wireless medium can be harvested or recycled

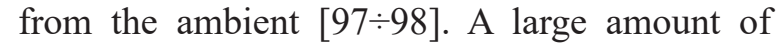
RF energy involves transmitting but only small amount can be harvested in real time, while the rest absorbed by the other materials or dissipates in heat energy [97]. Like in the case of other sources available in the environment and helpful for the production of free energy, RF energy is also available in large quantities and has potential to generate electrical energy $[99 \div 100]$. The mechanism of radio frequency energy harvesting consists of a receiving antenna, matching circuit, frequency detector and electric voltage. The function of antenna is to receive electromagnetic waves using a matching circuit to amplified voltage and the system capable of converting radio frequency into direct current. The maximum theoretical power of RF energy harvesting is $7.0 \mu \mathrm{W}$ and $1.0 \mu \mathrm{W}$ for $2.4 \mathrm{GHz}$ and $900 \mathrm{MHz}$ frequency, respectively, for free space distance of 40 meters [97, 101]. According to Le, [102] signals path loss will be different depending on the capturing environment, in contrast to free space environment. Antenna plays a significant role in the RF energy harvesting. The output or the efficiency of RF energy harvesting highly depends on anten-

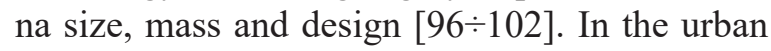
populated regions, different types of radio waves are freely available. These waves carry abundant energy which can be harvested using the RF energy harvesting techniques [95]. Literature showed sufficient data on the RF energy harvesting potential. The RF energy harvesting has opened new research opportunities for wireless and networking communication to harvest energy and use for the devices that need micro energy in the range of $\left(10^{-3}-10^{-6}\right)[97 \div 99]$.

\section{Air Flow}

At present, world is full of well-developed microelectronic technologies [95] and micro energy harvesting has successfully attracted attention $[103 \div 104]$. The airflow from the air conditioning equipment in the buildings can be harvested and wind turbine technology is one approach to harvest the airflow $[105 \div 107]$. Re- searchers were able to draw the output of micro wind turbine as Federspiel, [108] has designed $10.2 \mathrm{~cm}$ diameter fan rotor at air velocity $2.5 \mathrm{~m} / \mathrm{s}$ output $8 \mathrm{~mW}$ energy produces increasing air velocity $5.1 \mathrm{~m} / \mathrm{s}$, respectively, which has increased the energy to $28 \mathrm{~mW}$. Study of Rancourt, [109] reduced the size of rotor fan to $4.2 \mathrm{~cm}$ diameter output obtaining $2.4 \mathrm{~mW}$ at $5.5 \mathrm{~m} / \mathrm{s}$ air velocity and $130 \mathrm{~mW}$ at $11.8 \mathrm{~m} / \mathrm{s}$. Howey, [110] designed a rotor fan of $1.5 \mathrm{~cm}^{2}$ and $4.3 \mathrm{~mW}$ energy was produce at airflow velocity of $10 \mathrm{~m} / \mathrm{s}$ as a result. Generally, the power harvested from the airflow mechanism depends on the air/wind velocity, wind density and fans curve area of interaction with air [106, 107, 110, 111].

The power generated using airflow technique is measured as:

$$
P_{\text {out }}=1 / 2 \rho A V^{3} \eta_{g} C_{p}
$$

Where: $P_{\text {out }}$ is the converted electrical energy (W), $A$ is the area of wind turbine $\left(\mathrm{cm}^{2}\right)$, $\rho$ air density $\mathrm{kg} . \mathrm{m}^{-3}, \eta_{g}$ is the efficiency of generator, $C_{p}$ is the theoretical limit and $C_{p}$ is less than 0.59 as in 1919 , Albert Betz determined that a wind turbine cannot convert more than $59 \%$ of the kinetic energy of the wind $[112 \div 114]$. Hence, its micro level airflow energy is expected to have lesser $C_{p}$ value. Literature studies indicated that the maximum efficacy achieved using micro wind turbine is $10 \%$ $[110 \div 115]$. In order to increase the air generator performance efficiency Carli, [116] established a buck-boost converter. As a result, the result generator efficiency has increased. A study found that the airflow micro energy can be harvest using the wind turbine technique [117]. In majority, future studies focus on increasing the efficiency of airflow energy.

\section{Thermal Energy/ Thermoelectric Energy}

Our surroundings are full of many sources which generate natural temperature gradient between $10^{\circ} \mathrm{C}$ to $100^{\circ} \mathrm{C}$ like vehicle exhausts, fossil fuelled power generation, petrochemical plants, metals melting, glass and paper manufacturing, etc. The generated temperature gradient can be harvested to convert electrical energy conditionally [118 $\div 121]$. Electric/energy potential present due to the temperature gradient between two bodies is known as thermoelectricity [122]. Thermoelectricity is available into two forms temperature gradi- 
ent or temperature time-variation. Thermoelectric effect and pyro-electric effect are two methods to generate electrical energy from the thermal energy [122 $\div 124]$. In the method of thermoelectric energy harvesting, temperature is maintained through temperature gradient in the material and electrical energy is produced [125]. Thermoelectric energy produces via three different effects: the seebeck effect, the Peltier effect and the Thomson effect which is reversible in the thermodynamics $[124 \div 127]$. Seebeck is among the most common and interesting effects of thermal electric effect which produce the electrical energy due to the difference of temperature in the body. Thermoelectric generator or Seebeck effect was introduced by Thomas Johann Seebeck in 1821 to convert direct temperature gradient into electrical energy $[126 \div 128]$. A study quoted by Chalasani and Conrad [122] stated that Seebeck heat pump was designed by Sodano [129] to convert the temperature gradient available in the electrical power. Rowe, [130] developed large thermoelectric generator with the capacity of 100 watts and produced electrical energy from the hot waste water. Numerous studies were conducted to improve the efficiency of thermoelectric generator, as the current efficiency of TEG is less than $10 \%[123,131 \div 132]$. Pyroelectric energy harvesting is dependent on temperature time variation. In the contrast to thermoelectric energy, the pyroelectric energy does not need temperature gradient to convert thermal energy into electrical energy [123, 133, 134].
The phenomenon of pyroelectic energy is described when some materials generate electrical charge when heated. As a result of heating, the atoms of the material slightly change the position within the structure and polarization occurs. The polarization change of the material produces voltage in the material. Thus, the generated voltage can be converted to electrical energy within the temperature change variation $[123,135]$. Early theoretical studies on the pyroelectric energy were conducted by Clingman, [136] and Hoh, [137]. A study of Gonzalo, [138] suggested that the pyroelectic material efficiency can increase up to $4.0 \%$ by selecting proper material [139]. Ferro-electric transitions were found best for pyroelectric energy harvesting over small temperature variation, also increasing the efficiency $[140 \div 142]$. In conclusion, thermoelectric and pyroelectric methods have potential to produce and harvest micro energy by means of temperature gradient and real time temperature variation in the materials.

\section{Solar Energy Harvesting on Road Pavement}

The energy generated from the solar radiant was found the best among all others and is clean, eco-friendly as well as constitutes an infinite source of energy $[1,8,27,28,30,3233,77$, $78,82]$. There are various methods to produce solar energy, such as photo thermal, photovoltaic, photochemical and photo- biological con-

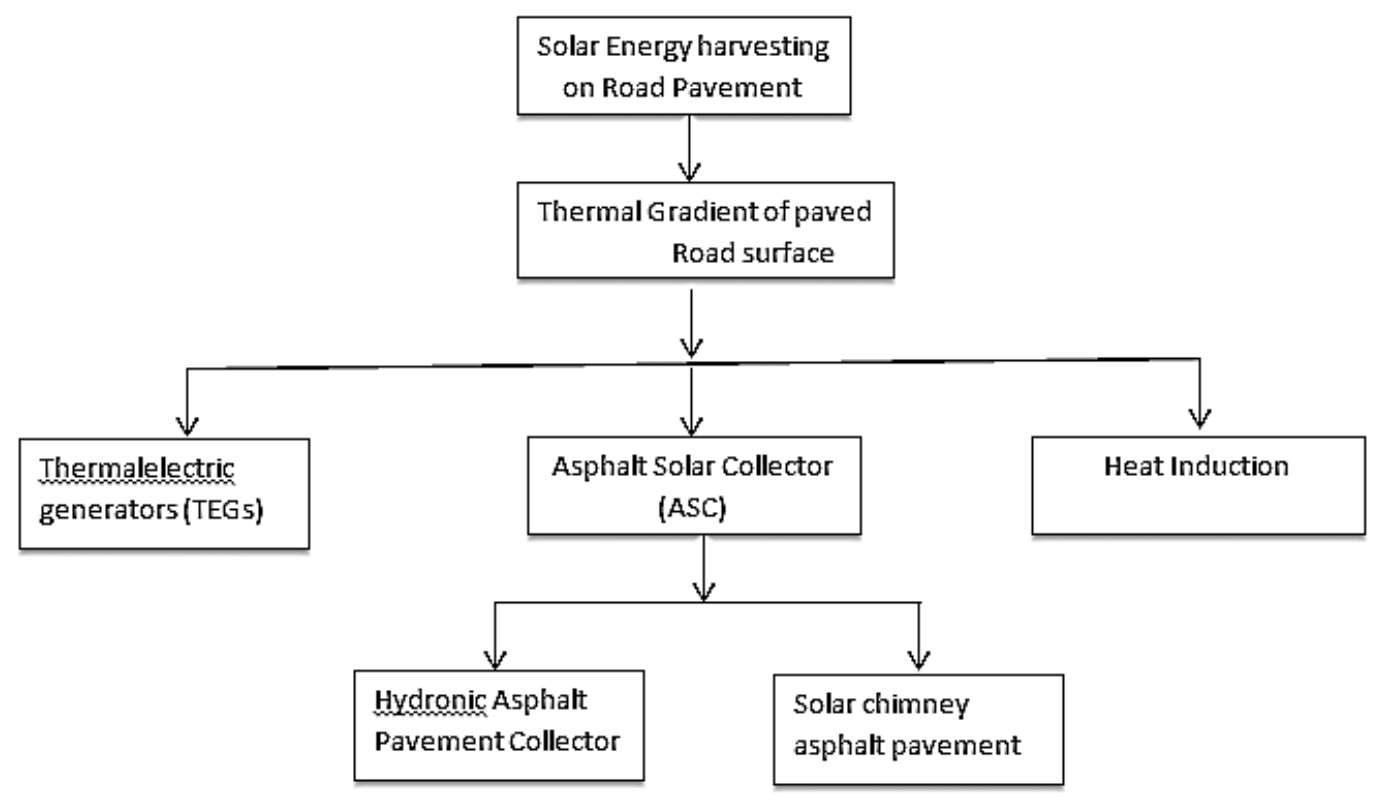

Fig. 12. Asphalt pavement energy harvesting technologies 
versions $[33,78,143]$. A new paradigm of the utilization of asphalt pavement as a solar collector includes the addition to self-powered energy harvesting and is categorized into two types solar radiation and vehicle load [73, 77, 144]. Dai$1 \mathrm{y}$, asphalt pavement received enormous amount of sun heat which get dissipates into the environment. Past studies found that bitumen asphalted surface may heat up to $70^{\circ} \mathrm{C}$ in summer by the direct solar radiation $[73,77,83,144 \div 150$, 168]. High temperature accelerates the thermal oxidation of asphalt pavement; hence, structural failure occurs and pavement performance is reduced [77, 151, 152].

Numerous studies focused on the asphalt solar collector (ASC) where the first and most important part covered is variation in the temperature of the outer and inner surface of the asphalt pavement at various depths followed by the embedded pipe material and arrangement. Formerly, metallic pipes made of steel; copper and iron were used due to high conductivity. However, high cost, corrosion and rigidity of the metallic pipes caused structural damages. Beside high potential of solar radiation collection asphalt pavement has high albedo rates at night and day time. Water is the most abundantly available fluid and best used in embedded pipes $[77,146 \div 160]$.

However, the solidification temperature of the circulating liquid should be lower than the expected lowest temperature of fluid as in some cases temperature drop below the freezing point and water can freeze in the embedded pipes and cause damage [153]. The arrangement of pipes is also an important parameter in asphalt solar collector (ASC) and the ongoing research studies also focus on the arrangement of the pipes, but literature shows that the parallel and serpentine arrangements have followed. Up to some extent, the serpentine arrangement was found more efficient than the parallel $[147 \div 148,158 \div 159]$.

\section{Thermoelectric generators (TEGs)}

In order to avoid the waste of micro thermal energy created within body, the thermoelectric generators (TEGs) technology has been introduced. TEGs implant between two heat exchangers which directly convert the heat energy into electrical energy due to the Seebeck effect [156, $161 \div 162]$. Utilization of thermoelectric generators (TEGs) in the road surface to collect waste heat energy through Seebeck effect is a new con- cept but lower efficiency is the main drawback $[163 \div 164]$. Experimental study conducted by Mallick,[161] implanting the TEGs into the asphalt pavement obtained the maximum power output of $5 \mathrm{~W}$ but did not calculate the efficiency. Wu and Yu, [165] implanted TEGs in the asphalt pavement surface. The maximum output efficiency was calculated as 4\% using Quantum Well structured (QW) materials. The efficiency of the TEGs is associated with the temperature gradient, the higher is the thermal gradient the more energy is generated and TEGs shows higher efficiency $[135,162,163,166,167]$.

\section{Induction Heat}

Asphalt itself is not an electrically conductive material but in the cooperation with other electrically conductive material that can be added to mixture, heating may be induced $[168 \div 169]$. The conductive material produces heat based on the Joule effect equation:

$$
P=R \cdot I^{2} . t
$$

Where: $P$ is the heat generated, $R$ is the material resistance, $I$ the current and the time of exposure to the magnetic field [170]. Selfhealing of the asphalt pavement against permanent deformation and minor or major cracks appearing in the asphalt pavement can occur if no more is applied to the surface that has been cracked $[171 \div 173]$. The electrically conductive material incorporation with pavement material can induce heat energy by solar irradiation and this energy can be harvest. The energy is induced using a conductive material in asphalt pavement to cope with the problem of cracks appearing in asphalt pavement to encourage self-healing techniques $[155,168 \div 173]$.

\section{Asphalt Solar Collector (ASC)}

Asphalt solar collector can be traced back to the year 1979 when it was patented by Wendal in the United States [174]. The purpose was deicing and melting snow during the winter snowing period. Moreover, to ensure road safety and smooth traffic flow especially on the bridges, ramps and road bends. Asphalt solar collector (ASC) was expended into hydronic asphalt pavement and solar air chimney method has been developed recently. 


\section{Hydronic Asphalt Solar Collector (HASC)}

Hydronic asphalt solar collector heat collection occurred in the pipes embedded underneath the wearing course which contains liquid (water or any other liquid). In the day light, the road surface temperature increases and temperature gradient between the fluid circulating in the pipes below the pavement surface is produced. The convection occurred where heat is transferred from the solid surface to the flowing liquid in the pipes and paved surface temperature decreases in the result of temperature stored in the flowing water. The store heat energy can be converted into thermal energy $[77,161,170,175]$. The Solar Energy Recuperation from the Road Pavement (SERSO) installed a hydronic asphalt solar collector (HASC) in Switzerland for the purpose of de-icing the snow from the bridge $[73,77,175]$. HASC was commercially applied by Road Energy System in Netherland to melt snow and harvest energy [176]. The use of hydronic asphalt solar collector (HASC) for snow melting was the subject of many studies and recently some companies have commercialized it, such as Dutch Ooms international holding with Road Energy System ${ }^{\circledR}$ (RES), WinnerWay, ICAX ${ }^{\mathrm{TM}}$ and Woecester Polytechnic Institute has a developed solar asphalt collector cited by [77, 150]. Studies focus on increasing the potential of hydronic asphalt solar collector by using different conductive materials. The major concern or drawback is the cracking appearing in the asphalt or the asphalt strength which can be improved using a polymer-modified bitumen as the previous result indicated that polymer-modified asphalt increases the strength of the asphalt pavement $[177 \div 178]$.

\section{Solar wind Turbine}

Recently, convection-powered air flow technique has been introduced by Garcia \& Partl [155] to manage the asphalt pavement temperature. The system of solar updraft towers and solar chimney consist of pipes embedded in paved surface. The air heated on the paved surface during day time creates an updraft air through the chimney [155, 178]. Air convection occurring in the chimney allows wind turbine to produce electrical energy. In addition Garcia \& Partl, [155] concluded that the air flowing through the embedded pipes in asphalt pavement can heat up and cool down up to $\pm 5^{\circ} \mathrm{C}$ and a significant reduction on the road surface temperature has been observed.
Additionally, the efficiency of solar wind turbine was studied versus the height of the chimney. The optimum height depended on the pipe material the chimney is made of but for the PVC chimney, $1 \mathrm{~m}$ to $1.5 \mathrm{~m}$ gives the maximum efficiency. The longer the height of chimney, the greater heat loss may be, in the contrast to the shorter chimney in which the air flow is very slow [155]. The subject of solar wind turbine in asphalt road has wide opportunity for study in the future; till now, only one study has conducted.

\section{CONCLUSION}

Energy is the key contributor to human basic needs; importantly, the economic growth of the country is highly dependent on the energy. Yet, fossil fuels are among the top sources of energy. In the past two decades, unprecedented changes in the consumption of fossil fuel energies had a drastic impact on the environment. As a result, the trend of investment in the renewable clean eco-friendly energies has grown worldwide. Nature can inspire innovative solutions for future energy systems and technology design. This paper confirmed the global resource of macro and micro energies potential in the current scenario.

Amongst the renewable energy resources, hydro energy is dominant with $71 \%$ global supply in 2015. Approximately $10,000 \mathrm{TWh} /$ Year of unutilized hydropower energy potential exists worldwide. Bioenergy plays a significant role in reducing the greenhouses gases and corresponded to $10 \%$ global renewable energy resources supplies. The electricity produced from the bioenergy constitutes the third largest renewable energy resource. Recently, waste disposal has become the greatest challenge worldwide. Scientists confirmed that recovery of heat energy or electricity from the waste was found among the most appropriate methods to solve the waste issues. Waste plastic products followed by papers, textiles and other waste organic materials have a high potential for reuse and produce energy. The review concluded that our planet has an infinite source of solar energy which radiates more energy than the consumed annually by the world population and has the highest potential to produce renewable energy. Recent development shows that the global contribution of solar energy to the renewable energy accounted for $1.0 \%$. The Earth's natural heat reserves are immense and geothermal energy 
has the highest capacity factor of $90 \%$ over other renewable energy technologies. Geothermal energy can play an important role in the countries that have potential like Indonesia and Turkey and USA, i.e. the leading countries producing geothermal energy. Wind power generation is an old technology but recently has attracted significant attention in terms of renewable energy production. Advanced development has occurred in the wind power harvesting technologies to overcome the wind speed and environmental challenges. An alternative design without rotor blades and the new Google Makani project to produce electricity from the wind were discussed. Demark produces the highest amount, i.e. $42 \%$ of wind power, followed by Germany with $13 \%$. Marine energy is an immense source of renewable energy and has a potential to play significant a role in the production of clean energy. Marine energy is categorized into seven sources including ocean wave, tidal range, tidal current, ocean current, ocean thermal energy, salinity gradient and ocean thermal energy conversion. Each source of marine energy plays a significant role and has potential but most of them are at the early stage of development.

The contribution of renewable energy resources is far slower than the energy produced from fossil fuels. Rapid development of technology and acceptance among the people, especially mobile devices consume micro energies. Selfpowered techniques used to harvest energy from the surrounding environment such as thermal variations within the body create light, thermal gradient, pressure gradient, air flow, vibration, radiofrequency or electromagnetic radiation. Each source of micro energy is well explained in the section above. Micro energy can be harvested from the waste vibration or thermal gradient present between two bodies. The study recommended the utilization of macro and micro energy resources which have huge potential to reduce the dependency on the fossil fuel will also help to reduce the environmental pollution.

\section{REFERENCES}

1. Varadi PF. Sun above the Horizon: Meteoric Rise of the Solar Industry. Pan Stanford; 2014 May 27. Google Scholar.

2. Eric P. Climate Change Denial Is the Original Fake News. The Environment. TIME, NewYork, 2017. Google Scholar.
3. McCright AM, Charters M, Dentzman K, Dietz T. Examining the effectiveness of climate change frames in the face of a climate change denial counter frame. Topics in Cognitive Science. 2016 Jan;8(1):76-97. doi.org/10.1111/tops. 12171.

4. Farmer GT, Cook J. Understanding climate change denial. InClimate change science: a modern synthesis 2013 (pp. 445-466). Springer, Dordrecht. Google Scholar.

5. Harris JM, Roach B. Environmental and Natural Resource Economics. A Contemporary Approach.ME Sharpe, Inc. Google Scholar.

6. Mbeva K, Pauw WP. Self-differentiation of countries' responsibilities. German Development Institute/Deutsches Institut für Entwicklungspolitik (DIE); 2016. Google Scholar.

7. Kousser T, Tranter B. The influence of political leaders on climate change attitudes. Global Environmental Change. 2018 May 31;50:100-9. doi. org/10.1016/j.gloenvcha.2018.03.005.

8. World Energy council, "World Energy Resources," London, 2016. Google Scholar.

9. Petroleum B. "Statistical Review of World Energy," BP Stat. Rev. World Energy, no. June, pp. 1-48, 2016.

10. Energy R. Accelerating the global energy transformation. International Renewable Energy Agency (IRENA). Abu Dhabi. 2017.Google Scholar.

11. Moriarty P, Honnery D. What is the global potential for renewable energy?. Renewable and Sustainable Energy Reviews. 2012 Jan 1;16(1):244-52. doi. org/10.1016/j.rser.2011.07.151.

12. Twidell J, Weir T. Renewable energy resources. Routledge; 2015 Jan 26. Google Scholar.

13. Darmawi, R. Sipahutar, S. M. Bernas and M. S. Imanuddin, "Renewable energy and hydropower utilization tendency worldwide," Renew. Sustain. Energy Rev., vol. 17, pp. 213-215, Jan. 2013. doi. org/10.1016/j.rser.2012.09.010.

14. Long H, Li X, Wang H, Jia J. Biomass resources and their bioenergy potential estimation: A review. Renewable and Sustainable Energy Reviews. 2013 Oct 1;26:344-52. doi.org/10.1016/j.rser.2013.05.035.

15. World Bioenergy Association. WBA global bioenergy statistics 2015. WBA. Obtenido de http:// www.worldbioenergy.org/sites/default/files/ WBA\% 20Global\% 20Bioener gy\% 20Statistics. 2015;202015:20. Google Scholar.

16. World Bioenergy Association. WBA Global Bioenergy Statistics. World Bioenergy Association: Stockholm, Sweden. 2017. Google Scholar.

17. Zhao XG, Jiang GW, Li A, Wang L. Economic analysis of waste-to-energy industry in China. Waste management. 2016 Feb 29;48:604-18. doi. org/10.1016/j.wasman.2015.10.014. 
18. Kumar A, Samadder SR. A review on technological options of waste to energy for effective management of municipal solid waste. Waste Management. 2017 Nov 1;69:407-22. doi.org/10.1016/j. wasman.2017.08.046.

19. Malinauskaite J, Jouhara H, Czajczyńska D, Stanchev P, Katsou E, Rostkowski P, Thorne RJ, Colón J, Ponsá S, Al-Mansour F, Anguilano L. Municipal solid waste management and waste-to-energy in the context of a circular economy and energy recycling in Europe. energy. 2017 Dec 15;141:201344. doi.org/10.1016/j.energy.2017.11.128.

20. Astrup TF, Tonini D, Turconi R, Boldrin A. Life cycle assessment of thermal waste-to-energy technologies: review and recommendations. Waste management. 2015 Mar 1;37:104-15. doi. org/10.1016/j.wasman.2014.06.011.

21. Ahmad M. Ayob M. "Improvement of Asphaltic Concrete by Using Waste Polyethylen Terephthalate (PET). International Journal of Innovative Research in Science, Engineering and Technology (IJIRSET). vol. 4, no. 8, pp. 6744-6753, 2015. DOI:10.15680/IJIRSET.2015.0408006.

22. Bajić BŽ, Dodić SN, Vučurović DG, Dodić JM, Grahovac JA. Waste-to-energy status in Serbia. Renewable and Sustainable Energy Reviews. 2015 Oct 1;50:1437-44. doi.org/10.1016/j. rser.2015.05.079.

23. Singh CK, Kumar A, Roy SS. Quantitative analysis of the methane gas emissions from municipal solid waste in India. Scientific reports. $2018 \mathrm{Feb}$ 13;8(1):2913. doi.org/10.1038/s41598-018-21326-9.

24. Hamad TA, Agll AA, Hamad YM, Sheffield JW. Solid waste as renewable source of energy: current and future possibility in Libya. Case studies in thermal Engineering. 2014 Nov 1;4:144-52. doi. org/10.1016/j.csite.2014.09.004.

25. Aracil C, Haro P, Giuntoli J, Ollero P. Proving the climate benefit in the production of biofuels from municipal solid waste refuse in Europe. Journal of cleaner production. 2017 Jan 20;142:2887-900. doi.org/10.1016/j.jclepro.2016.10.181.

26. Cantrell KB, Ro KS, Szögi AA, Vanotti MB, Smith MC, Hunt PG. Green farming systems for the Southeast USA using manure-to-energy conversion platforms. Journal of Renewable and Sustainable Energy. 2012 Jul;4(4):041401. doi. org/10.1063/1.3663846.

27. DeKay M, Brown GZ. Sun, wind, and light: architectural design strategies. John Wiley \& Sons; 2013 Dec 16. Google Scholar.

28. Kabir E, Kumar P, Kumar S, Adelodun AA, Kim KH. Solar energy: Potential and future prospects. Renewable and Sustainable Energy Reviews. 2018 Feb 1;82:894-900. doi.org/10.1016/j. rser.2017.09.094.
29. Reddy VS, Kaushik SC, Ranjan KR, Tyagi SK. State-of-the-art of solar thermal power plants-A review. Renewable and Sustainable Energy Reviews. 2013 Nov 1;27:258-73. doi.org/10.1016/j. rser.2013.06.037.

30. Solangi KH, Islam MR, Saidur R, Rahim NA, Fayaz H. A review on global solar energy policy. Renewable and sustainable energy reviews. 2011 May 1;15(4):2149-63. doi.org/10.1016/j. rser.2011.01.007.

31. Tietenberg TH, Lewis L. Environmental and natural resource economics. Routledge; 2016 Mar 4. Google Scholar.

32. Besarati SM, Padilla RV, Goswami DY, Stefanakos E. The potential of harnessing solar radiation in Iran: Generating solar maps and viability study of PV power plants. Renewable energy. 2013 May 1;53:193-9. doi.org/10.1016/j.renene.2012.11.012.

33. Kannan N, Vakeesan D. Solar energy for future world:-A review. Renewable and Sustainable Energy Reviews. 2016 Sep 1;62:1092-105. doi. org/10.1016/j.rser.2016.05.022.

34. Kim H, Kim HS, Ha J, Park NG, Yoo S. Solar Cells: Empowering Semi Transparent Solar Cells with Thermal Mirror Functionality (Adv. Energy Mater. 14/2016). Advanced Energy Materials. 2016 Jul;6(14). doi.org/10.1002/aenm.201670081.

35. Castillo CP, e Silva FB, Lavalle C. An assessment of the regional potential for solar power generation in EU-28. Energy policy. 2016 Jan 1;88:86-99. doi. org/10.1016/j.enpol.2015.10.004.

36. Hernandez RR, Easter SB, Murphy-Mariscal ML, Maestre FT, Tavassoli M, Allen EB, Barrows CW, Belnap J, Ochoa-Hueso R, Ravi S, Allen MF. Environmental impacts of utility-scale solar energy. Renewable and sustainable energy reviews. 2014 Jan 1;29:766-79. doi.org/10.1016/j. rser.2013.08.041.

37. Lu SM. A global review of enhanced geothermal system (EGS). Renewable and Sustainable Energy Reviews. 2018 Jan 1;81:2902-21. doi. org/10.1016/j.rser.2017.06.097.

38. Olasolo P, Juárez MC, Morales MP, Liarte IA. Enhanced geothermal systems (EGS): A review. Renewable and Sustainable Energy Reviews. 2016 Apr 1;56:133-44. doi.org/10.1016/j. rser.2015.11.031.

39. Barbier E. Geothermal energy technology and current status: an overview. Renewable and sustainable energy reviews. 2002 Jan 1;6(1-2):3-65. doi. org/10.1016/S1364-0321(02)00002-3.

40. Breede K, Dzebisashvili K, Liu X, Falcone G. A systematic review of enhanced (or engineered) geothermal systems: past, present and future. Geothermal Energy. 2013 Dec 1;1(1):4. doi. org/10.1186/2195-9706-1-4. 
41. Gondal IA, Masood SA, Amjad M. Review of geothermal energy development efforts in Pakistan and way forward. Renewable and Sustainable Energy Reviews. 2017 May 1;71:687-96. doi. org/10.1016/j.rser.2016.12.097.

42. Barnett PR, Mandagi S, Iskander T, Abidin Z, Armaladdoss A, Raad R. Exploration and Development of the Tawau Geothermal Project, Malaysia. InProceedings World Geothermal Congress 2015 2015 Apr (pp. 19-25). Google Scholar.

43. Amano RS. Review of Wind Turbine Research in 21 st Century. Journal of Energy Resources Technology. 2017 Sep 1;139(5):050801. doi: 10.1115/1.4037757.

44. Pieralli S, Ritter M, Odening M. Efficiency of wind power production and its determinants. Energy. 2015 Oct 1;90:429-38. doi.org/10.1016/j.energy.2015.07.055.

45. Gipe P. Wind power. Wind Engineering. 2004 Sep;28(5):629-31. doi. org/10.1260/0309524043028145.

46. Small L, Beirne S, Gutin O. Fact Sheet: Offshore Wind-can the United States Catch Up with Europe?. Environmental and Energy Study Institute, last modified January. 2016;4. Google Scholar.

47. Pelc R, Fujita RM. Renewable energy from the ocean. Marine Policy. 2002 Nov 1;26(6):471-9. doi.org/10.1016/S0308-597X(02)00045-3.

48. Armaroli N, Balzani V. The future of energy supply: challenges and opportunities. Angewandte Chemie International Edition. 2007 Jan;46(12):5266. doi.org/10.1002/anie.200602373.

49. Panwar NL, Kaushik SC, Kothari S. Role of renewable energy sources in environmental protection: a review. Renewable and Sustainable Energy Reviews. 2011 Apr 1;15(3):1513-24. doi. org/10.1016/j.rser.2010.11.037.

50. Hoegh-Guldberg O, Bruno JF. The impact of climate change on the world's marine ecosystems. Science. 2010 Jun 18;328(5985):1523-8. 10.1126/ science. 1189930.

51. Uihlein A, Magagna D. Wave and tidal current energy-A review of the current state of research beyond technology. Renewable and Sustainable Energy Reviews. 2016 May 1;58:1070-81. doi. org/10.1016/j.rser.2015.12.284

52. Smith HD, de Vivero JL, Agardy TS. Routledge Handbook of Ocean Resources and Management. Routledge; 2015 Oct 16. Google Scholar

53. Rhinefrank K, Schacher A, Prudell J, Hammagren E, von Jouanne A, Brekken T. Scaled development of a novel wave energy converter through wave tank to utility-scale laboratory testing. InPower \& Energy Society General Meeting, 2015 IEEE 2015 Jul 26 (pp. 1-5). IEEE. DOI: 10.1109/PESGM.2015.7286008.
54. Magagna D, Uihlein A. Ocean energy development in Europe: Current status and future perspectives. International Journal of Marine Energy. 2015 Sep 1;11:84-104. doi.org/10.1016/j.ijome.2015.05.001.

55. Antonio FD. Wave energy utilization: A review of the technologies. Renewable and sustainable energy reviews. 2010 Apr 1;14(3):899-918. doi. org/10.1016/j.rser.2009.11.003.

56. Mork G, Barstow S, Kabuth A, Pontes MT. Assessing the global wave energy potential. InASME 2010 29th International conference on ocean, offshore and arctic engineering 2010 Jan 1 (pp. 447454). American Society of Mechanical Engineers. 10.1115/OMAE2010-20473.

57. Borthwick AG. Marine renewable energy seascape. Engineering. 2016 Mar 1;2(1):69-78. doi. org/10.1016/J.ENG.2016.01.011.

58. Owen A. Tidal current energy: origins and challenges. InFuture energy 2008 (pp. 111-128). doi. org/10.1016/B978-0-08-054808-1.00007-7.

59. Gorlov AM. Tidal energy. Academic, London. 2001:2955-60. Google Scholar.

60. Charlier RH, Justus JR. Ocean energies: environmental, economic and technological aspects of alternative power sources. Elsevier; 1993 Sep 17. Google Scholar.

61. Bahaj AS. Generating electricity from the oceans. Renewable and Sustainable Energy Reviews. 2011 Sep 1;15(7):3399-416. doi.org/10.1016/j. rser.2011.04.032.

62. Nihous GC. Mapping available Ocean Thermal Energy Conversion resources around the main Hawaiian Islands with state-of-the-art tools. Journal of Renewable and Sustainable Energy. 2010 Jul;2(4):043104. doi.org/10.1063/1.3463051.

63. Andrawina YO, Sugianto DN, Alifdini I. Initial Study Of Potency Thermal Energy Using OTEC (Ocean Thermal Energy Conversion) As A Renewable Energy For Halmahera Indonesia. InIOP Conference Series: Earth and Environmental Science 2017 Feb (Vol. 55, No. 1, p. 012032). IOP Publishing. doi.org/10.1088/1755-1315/55/1/012032.

64. Masutani SM, Takahashi PK. Ocean thermal energy conversion (OTEC). Oceanography. 2001;22(609):625. Google Scholar.

65. Chan M. Ocean thermal energy conversion. Penn Sustainability Review. 2015;1(7):9. Google Scholar.

66. Schaetzle O, Buisman CJ. Salinity gradient energy: current state and new trends. doi.org/10.15302/JENG-2015046.

67. Pattle RE. Production of electric power by mixing fresh and salt water in the hydroelectric pile. Nature. 1954 Oct;174(4431):660. Google Scholar Google Scholar 
68. Emami Y, Mehrangiz S, Etemadi A, Mostafazadeh A, Darvishi S. A brief review about salinity gradient energy. Int. J. Smart Grid Clean Energy. 2013;2:295-300. Google Scholar.

69. Tamburini A, Cipollina A, Papapetrou M, Piacentino A, Micale G. Salinity gradient engines. In Sustainable energy from salinity gradients 2016 (pp. 219-256). doi.org/10.1016/B978-0-08-1003121.00007-9.

70. Isaacs JD, Seymour RJ. The ocean as a power resource. international journal of environmental studies. 1973 Jan 1;4(1-4):201-5. doi. org/10.1080/00207237308709563.

71. Logan BE, Elimelech M. Membrane-based processes for sustainable power generation using water. Nature. 2012 Aug;488(7411):313. Google Scholar.

72. Zhu Y, Wang W, Cai B, Hao J, Xia R. The salinity gradient power generating system integrated into the seawater desalination system. InIOP Conference Series: Earth and Environmental Science 2017 Jan (Vol. 52, No. 1, p. 012067). IOP Publishing. doi.org/10.1088/1742-6596/52/1/012067.

73. Harb A. Energy harvesting: State-of-the-art. Renewable Energy. 2011 Oct 1;36(10):2641-54. doi. org/10.1016/j.renene.2010.06.014.

74. Banks D, Schäffler J. The potential contribution of renewable energy in South Africa. Sustainable Energy \& Climate Change Project (SECCP); 2005. Google Scholar.

75. Konovalov V, Pogharnitskaya O, Rostovshchikova $A$, Matveenko I. Potential of renewable and alternative energy sources. InIOP Conference Series: Earth and Environmental Science 2015 (Vol. 27, No. 1, p. 012068). IOP Publishing. doi. org/10.1088/1755-1315/27/1/012068.

76. Mariam L, Basu M, Conlon MF. A review of existing microgrid architectures. Journal of Engineering. 2013;2013. dx.doi.org/10.1155/2013/937614.

77. Bobes-Jesus V, Pascual-Muñoz P, Castro-Fresno D, Rodriguez-Hernandez J. Asphalt solar collectors: a literature review. Applied Energy. 2013 Feb 1;102:962-70. doi.org/10.1016/j.apenergy.2012.08.050.

78. Singh GK. Solar power generation by PV (photovoltaic) technology: A review. Energy. 2013 May 1;53:1-3. doi.org/10.1016/j.energy.2013.02.057.

79. Abolhosseini S, Heshmati A, Altmann J. A review of renewable energy supply and energy efficiency technologies. Google Scholar.

80. Selvan KV, Ali MS. Micro-scale energy harvesting devices: Review of methodological performances in the last decade. Renewable and Sustainable Energy Reviews. 2016 Feb 1;54:1035-47. doi. org/10.1016/j.rser.2015.10.046.

81. Muhtaroğlu A. Micro-scale Energy Harvesting for
Batteryless Information Technologies. InEnergy Harvesting and Energy Efficiency 2017 (pp. 6385). Springer, Cham. doi.org/10.1007/978-3-31949875-1_3.

82. Khaligh A, Onar OC. Energy harvesting: solar, wind, and ocean energy conversion systems. CRC press; 2009 Dec 1. Google Scholar.

83. Lu C, Raghunathan V, Roy K. Efficient design of micro-scale energy harvesting systems. IEEE Journal on Emerging and Selected Topics in Circuits and Systems. 2011 Sep;1(3):254-66. 10.1109/JETCAS.2011.2162161.

84. Wei C, Jing X. A comprehensive review on vibration energy harvesting: Modelling and realization. Renewable and Sustainable Energy Reviews. 2017 Jul 1;74:1-8. doi.org/10.1016/j.rser.2017.01.073.

85. Fang LH, Hassan SI, Rahim RB, Malek MF. A study of vibration energy harvester. ARPN Journal of Engineering and Applied Sciences. 2016: Vol 8.11. Google Scholar.

86. Kirubaveni S, Radha S. Vibration energy harvesting for low power devices. InGreen Engineering and Technologies (IC-GET), 2016 Online International Conference on 2016 Nov 19 (pp. 1-4). IEEE. 10.1109/GET.2016.7916705.

87. Dipak S, Rajarathinam M, Ali SF. Energy harvesting dynamic vibration absorber under random vibration. In2013 IEEE International Conference on Control Applications (CCA) 2013 Aug 28 (pp. 1241-1246). IEEE. DOI: 10.1109/ CCA.2013.6662922.

88. Green PL, Papatheou E, Sims ND. Energy harvesting from human motion and bridge vibrations: An evaluation of current nonlinear energy harvesting solutions. Journal of Intelligent Material Systems and Structures. 2013 Aug;24(12):1494-505. doi. org/10.1177/1045389X12473379.

89. Griffin MJ. Handbook of human vibration. Academic press; 2012 Dec 2. Google Scholar.

90. Vullers RJ, van Schaijk R, Doms I, Van Hoof C, Mertens R. Micropower energy harvesting. SolidState Electronics. 2009 Jul 1;53(7):684-93. doi. org/10.1016/j.sse.2008.12.011.

91. Beeby SP, Torah RN, Tudor MJ, Glynne-Jones P, O'donnell T, Saha CR, Roy S. A micro electromagnetic generator for vibration energy harvesting. Journal of Micromechanics and microengineering. 2007 Jun 5;17(7):1257. doi.org/10.1088/09601317/17/7/007.

92. Roundy S, Wright PK. A piezoelectric vibration based generator for wireless electronics. Smart Materials and structures. 2004 Aug 11;13(5):1131. doi.org/10.1088/0964-1726/13/5/018.

93. Minazara E, Vasic D, Costa F. Piezoelectric generator harvesting bike vibrations energy to supply portable devices. InProceedings of International Con- 
ference on Renewable Energies And Power Quality (ICREPQ’08) 2008 Mar 12. Google Scholar.

94. Starner T, Paradiso JA. Human generated power for mobile electronics. Low power electronics design. 2004 Dec;45:1-35. Google Scholar.

95. Verschaeve L. Environmental impact of radiofrequency fields from mobile phone base stations. Critical Reviews in Environmental Science and Technology. 2014 Jun 18;44(12):1313-69. doi.org /10.1080/10643389.2013.781935.

96. Hardell L, Carlberg M, Hedendahl LK. Radiofrequency radiation from nearby base stations gives high levels in an apartment in Stockholm, Sweden: A case report. Oncology letters. 2018 May 1;15(5):7871-83. doi.org/10.3892/ol.2018.8285.

97. Pirapaharan K, Gunawickrama K, De Silva DS, De Silva MS, Dharmawardhana TL, Indunil WG, Wickramasinghe CB, Aravind CV. Energy harvesting through the radio frequency wireless power transfer. InRF and Microwave Conference (RFM), 2013 IEEE International 2013 Dec 9 (pp. 376-381). DOI: $10.1109 /$ RFM.2013.6757288.

98. Mouapi A, Hakem N, Delisle GY. A new approach to design of RF energy harvesting system to enslave wireless sensor networks. ICT Express. 2017 Dec 23. doi.org/10.1016/j.icte.2017.11.002.

99. Aparicio MP, Bakkali A, Pelegri-Sebastia J, Sogorb T, Llario V, Bou A. Radio frequency energy harvesting-sources and techniques. InRenewable Energy-Utilisation and System Integration 2016. InTech. DOI:10.5772/61722.

100. Lu X, Wang P, Niyato D, Kim DI, Han Z. Wireless networks with RF energy harvesting: A contemporary survey. IEEE Communications Surveys \& Tutorials. 2015 May;17(2):757-89. DOI: 10.1109/COMST.2014.2368999.

101. Zungeru AM, Ang LM, Prabaharan S, Seng KP. Radio frequency energy harvesting and management for wireless sensor networks. Green mobile devices and networks: Energy optimization and scavenging techniques. 2012 Mar 5:341-68. Google Scholar.

102. Le TT. Efficient power conversion interface circuits for energy harvesting applications. 2008. Phd Theis. https://ir.library.oregonstate.edu/concern/ graduate_thesis_or_dissertations $/ 5 \mathrm{q} 47 \mathrm{rr} 95 \mathrm{w}$.

103. Sun H, Zhu D, White NM, Beeby SP. A miniature airflow energy harvester from piezoelectric materials. InJournal of physics: Conference series 2013 (Vol. 476, No. 1, p. 012057). IOP Publishing. doi.org/10.1088/1742-6596/476/1/012057.

104. Najafi K. Micro Energy Harvesters-An Alternative Source of Renewable Energy. 2010. Google Scholar.

105. Matiko JW, Grabham NJ, Beeby SP, Tudor MJ.
Review of the application of energy harvesting in buildings. Measurement Science and Technology. 2013 Nov 13;25(1):012002. doi. org/10.1088/0957-0233/25/1/012002.

106. Weimer MA, Paing TS, Zane RA. Remote area wind energy harvesting for low-power autonomous sensors. InPower Electronics Specialists Conference, 2006. PESC'06. 37th IEEE 2006 Jun 18 (pp. 1-5). DOI: 10.1109/pesc.2006.1712213.

107. Boccalero G, Boragno C, Morasso R, Caviglia DD. Efficiency Issues for a Wind-Driven Energy Harvesting Device. Journal of Low Power Electronics. 2018 Mar 1;14(1):140-7. doi.org/10.1166/ jolpe.2018.1534.

108. Khan FU, Iqbal M. Development of a testing rig for vibration and wind based energy harvesters. Journal of Engineering and Applied Sciences. 2016;35(2):101-10. Google Scholar.

109. Rancourt D, Tabesh A, Fréchette LG. Evaluation of centimeter-scale micro windmills: aerodynamics and electromagnetic power generation. Proc. PowerMEMS. 2007 Nov 28;20079. Google Schola.r

110. Howey DA, Bansal A, Holmes AS. Design and performance of a centimetre-scale shrouded wind turbine for energy harvesting. Smart Materials and Structures. 2011 Jul 20;20(8):085021. doi. org/10.1088/0964-1726/20/8/085021.

111. Yang Z, Zhou S, Zu J, Inman D. High-performance piezoelectric energy harvesters and their applications. Joule. 2018 Apr 10. https://doi. org/10.1016/j.joule.2018.03.011.

112. Betz A. Windmills in the light of modern research.1928. Google Scholar.

113. Greet RJ. Maximum windmill efficiency. Journal of Applied Physics. 1980 Sep;51(9):4680-1. https://doi.org/10.1063/1.328340.

114. Malík M, Primas J, Kopecký V, Svoboda M. Calculation and measurement of a neutral air flow velocity impacting a high voltage capacitor with asymmetrical electrodes. AIP Advances. 2014 Jan;4(1):017137. doi.org/10.1063/1.4864181.

115. Casini M. Small vertical axis wind turbines for energy efficiency of buildings. Journal of Clean Energy Technologies. 2016 Jan;4(1):56-65. Google Scholar.

116. Carli D, Brunelli D, Bertozzi D, Benini L. A highefficiency wind-flow energy harvester using micro turbine. InPower electronics electrical drives automation and motion (SPEEDAM), 2010 international symposium on 2010 Jun 14 (pp. 778783). IEEE. 10.1109/SPEEDAM.2010.5542121.

117. Prauzek M, Konecny J, Borova M, Janosova K, Hlavica J, Musilek P. Energy harvesting sources, storage devices and system topologies for envi- 
ronmental wireless sensor networks: A review. Sensors. 2018 Aug;18(8):2446. DOI: 10.3390/ s18082446.

118. Hashim HT. Energy Harvesting from the Waste Heat of an Electrical Oven via Thermoelectric Generator. InJournal of Physics: Conference Series 2018 May (Vol. 1032, No. 1, p. 012024). IOP Publishing. doi.org/10.1088/17426596/1032/1/012024.

119. Shibata T, Fukuzumi Y, Kobayashi W, Moritomo Y. Thermal power generation during heat cycle near room temperature. Applied Physics Express. 2017 Dec 8;11(1):017101. doi.org/10.7567/ APEX.11.017101.

120. Yoshida J, Morimoto K, Suzuki Y. Electrostatic thermal energy harvester using unsteady temperature change. InJournal of Physics: Conference Series 2013 (Vol. 476, No. 1, p. 012079). IOP Publishing. doi.org/10.1088/17426596/476/1/012079.

121. Hunter SR, Lavrik NV, Mostafa S, Rajic S, Datskos PG. Review of pyroelectric thermal energy harvesting and new MEMs-based resonant energy conversion techniques. InEnergy Harvesting and Storage: Materials, Devices, and Applications III 2012 May 25 (Vol. 8377, p. 83770D). International Society for Optics and Photonics. doi.org/10.1117/12.920978.

122. Chalasani S, Conrad JM. A survey of energy harvesting sources for embedded systems. InSoutheastcon, 2008. IEEE 2008 Apr 3 (pp. 442-447). IEEE. Google Scholar.

123. Zhu H. Thermal energy harvesting from temperature fluctuations. 2011. (Doctoral dissertation, Lyon, INSA). Google Scholar.

124. Zhang X, Zhao LD. Thermoelectric materials: Energy conversion between heat and electricity. Journal of Materiomics. 2015 Jun 1;1(2):92-105. doi.org/10.1016/j.jmat.2015.01.001.

125. Gould C, Edwards R. Review on micro-energy harvesting technologies. InPower Engineering Conference (UPEC), 2016 51st International Universities 2016 Sep 6 (pp. 1-5). IEEE. DOI: 10.1109/UPEC.2016.8114023.

126. Lee HS. Thermal design: heat sinks, thermoelectrics, heat pipes, compact heat exchangers, and solar cells. John Wiley \& Sons; 2010 Nov 17. Google Scholar.

127. Yin L, Yang L, Yang W, Guo Y, Ma K, Li S, Zhang J. Thermal design and analysis of multichip LED module with ceramic substrate. SolidState Electronics. 2010 Dec 1;54(12):1520-4. doi. org/10.1016/j.sse.2010.06.028.

128. Adroja MN, Mehta SB, Shah MP. Review of thermoelectricity to improve energy quality. InInternational Journal of Emerging Technologies and Innovative Research JETIR 2015 Mar (Vol. 2, No. 3 (March-2015)). JETIR. Google Scholar.

129. Sodano HA, Dereux R, Simmers GE, Inman DJ. Power harvesting using thermal gradients for recharging batteries. InProceedings of 15 th international conference on adaptive structures and technologies 2004 Oct 25 (pp. 25-27). Google Scholar.

130. Rowe DM. Thermoelectric waste heat recovery as a renewable energy source. International Journal of Innovations in Energy Systems and Power. 2006 Nov;1(1):13-23. Google Scholar.

131. LeBlanc S. Thermoelectric generators: Linking material properties and systems engineering for waste heat recovery applications. Sustainable Materials and Technologies. 2014 Dec 1;1:26-35. doi.org/10.1016/j.susmat.2014.11.002.

132. Hapenciuc CL, Borca-Tasciuc T, Mihailescu IN. The relationship between the thermoelectric generator efficiency and the device engineering figure of merit $\mathrm{Zd}$, eng. The maximum efficiency max. AIP Advances. 2017 Apr;7(4):045007. doi. org/10.1063/1.4979328.

133. Sebald G, Lefeuvre E, Guyomar D. Pyroelectric energy conversion: Optimization principles. ieee transactions on ultrasonics, ferroelectrics, and frequency control. 2008 Mar;55(3). DOI: 10.1109/TUFFC.2008.680.

134. Hsiao CC, Siao AS. Improving pyroelectric energy harvesting using a sandblast etching technique. Sensors. 2013 Sep 10;13(9):12113-31. doi. org/10.3390/s130912113.

135. Tang ZB, Deng YD, Su CQ, Shuai WW, Xie CJ. A research on thermoelectric generator's electrical performance under temperature mismatch conditions for automotive waste heat recovery system. Case Studies in Thermal Engineering. 2015 Mar 1;5:143-50. doi.org/10.1016/j.csite.2015.03.006.

136. Clingman WH, Moore Jr RG. Application of ferroelectricity to energy conversion processes. Journal of Applied Physics. 1961 Apr;32(4):67581. doi.org/10.1063/1.1736069.

137. Hoh SR. Conversion of thermal to electrical energy with ferroelectric materials. Proceedings of the IEEE. 1963 May;51(5):838-45. DOI: 10.1109/ PROC.1963.2277.

138. Gonzalo JA. Ferroelectric materials as energy converters. Ferroelectrics. 1976 Jan 1;11(1):4239. doi.org/10.1080/00150197608237774.

139. Li Z, Zhou G, Zhu Z, Li W. A study on the power generation capacity of piezoelectric energy harvesters with different fixation modes and adjustment methods. Energies. 2016 Feb 19;9(2):98. doi:10.3390/en9020098.

140. Sebald G, Pruvost S, Guyomar D. Energy harvesting based on Ericsson pyroelectric cycles in 
a relaxor ferroelectric ceramic. Smart Materials and Structures. 2007 Dec 3;17(1):015012. doi. org/10.1088/0964-1726/17/01/015012.

141. Mohammadi S, Khodayari A. Pyroelectric energy harvesting: with thermodynamic-based cycles. Smart Materials Research. 2012;2012. dx.doi. org/10.1155/2012/160956.

142. Lee FY, Goljahi S, McKinley IM, Lynch CS, Pilon L. Pyroelectric waste heat energy harvesting using relaxor ferroelectric 8/65/35 PLZT and the Olsen cycle. Smart Materials and Structures. 2012 Jan 26;21(2):025021. doi.org/10.1088/0964$1726 / 21 / 2 / 025021$.

143. Reddy VS, Kaushik SC, Ranjan KR, Tyagi SK. State-of-the-art of solar thermal power plants-A review. Renewable and Sustainable Energy Reviews. 2013 Nov 1;27:258-73. doi.org/10.1016/j. rser.2013.06.037.

144. Duarte F, Ferreira A. Energy harvesting on road pavements: state of the art. Proceedings of the institution of civil engineers. 2016 Mar 8;169:7990. doi.org/10.1680/muen.12.00025.

145. Pan P, Wu S, Xiao Y, Liu G. A review on hydronic asphalt pavement for energy harvesting and snow melting. Renewable and Sustainable Energy Reviews. 2015 Aug 1;48:624-34. doi.org/10.1016/j. rser.2015.04.029.

146. Beddu S, Talib SH, Itam Z. The Potential of Heat Collection from Solar Radiation in Asphalt Solar Collectors in Malaysia. InIOP Conference Series: Earth and Environmental Science 2016 Mar (Vol. 32, No. 1, p. 012045). IOP Publishing. doi:10.1088/1755-1315/32/1/012045.

147. Beddu S, Itam Z, Ahmad M, Alanimi F.B, and Zainoodin M. "Thermal Behavior of Asphalt Pavement as an Active Solar Collector under Malaysia Climate Condition Using Rubber Tube," J. Eng. Appl. Sci. , vol. 13, no. 7, pp. 1690-1695, 2018. Medwell. Google Scholar.

148. Ahmad M, Itam ZB, Beddu S, Alanimi FB, Soanathan SA. A determination of solar heat collection in sepertine copper and rubber pipe embedded in asphalt pavement using finite element method. J. Eng. Appl. Sci., vol. 13, no. 1, pp. 181-189, 2018. Medwell. Google Scholar.

149. Basheer Sheeba J, Krishnan Rohini A. Structural and thermal analysis of asphalt solar collector using finite element method. Journal of Energy. 2014;2014. dx.doi.org/10.1155/2014/602087.

150. Mallick RB, Chen BL, Bhowmick S. Harvesting energy from asphalt pavements and reducing the heat island effect. International Journal of Sustainable Engineering. 2009 Sep 1;2(3):214-28. doi.org/10.1080/19397030903121950.

151. Liang G, Li P. Research on Thermoelectric Transducers for Harvesting Energy from Asphalt Pave- ment Based on Seebeck Effects. CRC Press, Boca Raton, Fla; 2015 May 14. Google Scholar.

152. Han R, Jin X, Glover CJ. Modeling pavement temperature for use in binder oxidation models and pavement performance prediction. Journal of Materials in Civil Engineering. 2011 Mar 15;23(4):351-9. doi.org/10.1061/(ASCE) MT.1943-5533.0000169.

153. Tongyan P, Yang L, Zhaoyang W. Development of an atomistic-based chemophysical environment for modelling asphalt oxidation. Polymer degradation and stability. 2012 Nov 1;97(11):2331-9. doi.org/10.1016/j.polymdegradstab.2012.07.032.

154. Yavuzturk C, Ksaibati K, Chiasson AD. Assessment of temperature fluctuations in asphalt pavements due to thermal environmental conditions using a two-dimensional, transient finitedifference approach. Journal of Materials in Civil Engineering. 2005 Aug;17(4):465-75. doi. org/10.1061/(ASCE)0899-1561(2005)17:4(465).

155. García A, Partl MN. How to transform an asphalt concrete pavement into a solar turbine. Applied Energy. 2014 Apr 15;119:431-7. doi. org/10.1016/j.apenergy.2014.01.006.

156. Loomans MG, Oversloot H, De Bondt A, Jansen R, Van Rij H. Design tool for the thermal energy potential of asphalt pavements. InEighth International IBPSA Conference, Eindhoven, Netherlands 2003 Aug 11 (p. 745). Google Scholar.

157. Khoja AO, Waheeb SA. Exploring the Potentials of Asphalt Solar Collectors in Hot Humid Climates. Innov Ener Res. 2016;5(141):2. Google Scholar.

158. Wu S, Wang H, Chen M, Zhang Y. Numerical and experimental validation of full-depth asphalt slab using capturing solar energy. InBioinformatics and Biomedical Engineering (iCBBE), 2010 4th International Conference on 2010 Jun 18 (pp. 1-4). IEEE. DOI: 10.1109/ICBBE.2010.5517215.

159. Chiarelli A, Dawson AR, Garcia A. Field evaluation of the effects of air convection in energy harvesting asphalt pavements. Sustainable Energy Technologies and Assessments. 2017 Jun 1;21:50-8. doi.org/10.1016/j.seta.2017.04.001.

160. Chen M, Wu S, Wang H, Zhang J. Study of ice and snow melting process on conductive asphalt solar collector. Solar Energy Materials and Solar Cells. 2011 Dec 1;95(12):3241-50. doi.org/10.1016/j. solmat.2011.07.013.

161. Li W, Paul MC, Siviter J, Montecucco A, Knox AR, Sweet T, Min G, Baig H, Mallick TK, Han G, Gregory DH. Thermal performance of two heat exchangers for thermoelectric generators. Case Studies in Thermal Engineering. 2016 Sep 1;8:164-75. doi.org/10.1016/j.csite.2016.06.008.

162. Guo L, Lu Q. Potentials of piezoelectric and ther- 
moelectric technologies for harvesting energy from pavements. Renewable and Sustainable Energy Reviews. 2017 May 1;72:761-73. doi. org/10.1016/j.rser.2017.01.090.

163. Montecucco A, Siviter J, Knox AR. The effect of temperature mismatch on thermoelectric generators electrically connected in series and parallel. Applied Energy. 2014 Jun 15;123:47-54. doi. org/10.1016/j.apenergy.2014.02.030.

164. Borgström F, Coyet J. Waste heat recovery system with new thermoelectric materials. Applied Thermodynamics and Fluid Mechanics. Master Thesis. 2015. Google Scholar.

165. Wu G, Yu X. Thermal energy harvesting across pavement structure. 2012. Google Schoalr.

166. Duarte FJ. Pavement Energy Harvesting System to Convert Vehicles Kinetic Energy into Electricity (Doctoral dissertation, 00500:: Universidade de Coimbra). Google Scholar.

167. Wu GX, Yu BX. Computer-aided design of thermal energy harvesting system across pavement structure. International Journal of Pavement Research and Technology. 2013 Mar 1;6(2):73-9. doi 10.6135/ijprt.org.tw/2013.6(2).73.

168. Vo HV, Park DW. Application of Conductive Materials to Asphalt Pavement. Advances in Materials Science and Engineering. 2017;2017. doi. org/10.1155/2017/4101503.

169. Pan P, Wu S, Xiao F, Pang L, Xiao Y. Conductive asphalt concrete: A review on structure design, performance, and practical applications. Journal of Intelligent Material Systems and Structures. 2015 May;26(7):755-69. doi. org/10.1177/1045389X14530594.

170. Partl MN. Towards improved testing of modern asphalt pavements. Materials and Structures. 2018 Dec 1;51(6):166. doi.org/10.1617/s11527-
018-1286-9

171. García Á, Schlangen E, van de Ven M, Liu Q. Electrical conductivity of asphalt mortar containing conductive fibers and fillers. Construction and building materials. 2009 Oct 1;23(10):3175-81. doi.org/10.1016/j.conbuildmat.2009.06.014.

172. Al-Mansoori T, Norambuena-Contreras J, Garcia A. Effect of capsule addition and healing temperature on the self-healing potential of asphalt mixtures. Materials and Structures. 2018 Apr 1;51(2):53. doi.org/10.1617/s11527-018-1172-5.

173. Sun D, Pang Q, Zhu X, Tian Y, Lu T, Yang Y. Enhanced self-healing process of sustainable asphalt materials containing microcapsules. ACS Sustainable Chemistry \& Engineering. 2017 Oct 6;5(11):9881-93. doi: 10.1021/ acssuschemeng.7b01850.

174. Wendel IL. Paving and Solar Energy System and Method. United States Patent, 4132074. 1979. Google Scholar.

175. Lund JW. Pavement snow melting. Geo-Heat Center, Oregon Institute of Technology, Klamath Falls, OR. 2002. Google Scholar.

176. Lai J, Qiu J, Chen J, Fan H, Wang K. New technology and experimental study on snow-melting heated pavement system in tunnel portal. Advances in Materials Science and Engineering. 2015;2015. dx.doi.org/10.1155/2015/706536.

177. Ahmad M, Ayob MB. Improvement of road pavement infrastructure by using polyethylene terephthalate and polypropylene. In Proceedings of 23rd The IIER International Conference, Singapore 2015 (pp. 48-53). Google Scholar.

178. Dezfooli AS, Nejad FM, Zakeri H, Kazemifard S. Solar pavement: A new emerging technology. Solar Energy. 2017 Jun 1;149:272-84. doi. org/10.1016/j.solener.2017.04.016. 